\title{
RADIAÇÃO E CRESCIMENTO DE PLANTAS JOVENS DE AÇAÍ EM SISTEMAS AGROFLORESTAIS
}

\author{
LEILA SOBRAL SAMPAIO \\ Engenheira Agrônoma
}

Orientador: Prof. Dr. MARCOS SILVEIRA BERNARDES

\begin{abstract}
Tese apresentada à Escola Superior de Agricultura
"Luiz de Queiroz", Universidade de São Paulo, para obtenção do título de Doutor em Agronomia, Área de Concentração: Fitotecnia.
\end{abstract}

P IR A C I C A B A

Estado de São Paulo - Brasil

Dezembro - 2003 


\section{Errata}

LEILA SOBRAL SAMPAIO. Radiação e crescimento de plantas jovens de açai em sịstemas agroflorestais

\begin{tabular}{|c|c|c|c|c|}
\hline p. & item & linha & onde se lê & leia-se \\
\hline 8 & 2.3 & vigésíma quinta & jussara... & ... juçara \\
\hline 9 & 2.4 & $\begin{array}{l}\text { vigésima primeira } \\
\text { e vigésima quarła }\end{array}$ & & \\
\hline 22 & 3.3 & oitava & $M=0,098+360,08\left[0,33(D / 2)^{2} H A F\right]$ & $M=0,098+360,08\left((D / 2)^{2} H \pi A F^{0,33}\right.$ \\
\hline 28 & 4.1 .2 & sexta & $\begin{array}{l}\text { Temperaturas média, máxima, } \\
\text { minima... }\end{array}$ & $\begin{array}{l}\text {...Temperatura máxima média, mínima } \\
\text { média ... }\end{array}$ \\
\hline 29 & 4.1 .2 & décima segunda & $\begin{array}{l}\text {... sob dossel chegando a } 50 \% \text { no mês } \\
\text { de março ... }\end{array}$ & $\begin{array}{l}\text {... sob dossel chegando a reduzir em } \\
50 \% \text { no mês de março... }\end{array}$ \\
\hline
\end{tabular}


Dados Internacionais de Catalogação na Publicação (CIP) DIVISÃO DE BIBLIOTECA E DOCUMENTAÇÃO - ESALQ/USP

\author{
Sampaio, Leila Sobral \\ Radiação e crescimento de plantas jovens de açaí em sistemas agroflorestais / Leila \\ Sobral Sampaio. - - Piracicaba, 2003. \\ 59 p. : il. \\ Tese (doutorado) - - Escola Superior de Agricultura Luiz de Queiroz, 2003. \\ Bibliografia. \\ 1. Açaí 2. Agrossilvicultura 3. Cacau 4. Irrigaçăo 5. Leucena 6.Seringueira 7. \\ Sombreamento I. Título
}

CDD 634.6

"Permitida a cópia total ou parcial deste documento, desde que citada a fonte - $\mathrm{O}$ autor" 


\section{AGRADECIMENTOS}

No percurso de elaboração do trabalho, estimulante e desafiador, muitos amigos e companheiros de trabalho estiveram presentes, e não poderia deixar de nomear e registrar aqui minha gratidão aos colegas Edson Roberto Teramoto, Aureny Lunz e Ciro Abbud Righi pelo apoio e ajuda incondicional.

Contudo, não poderia deixar de destacar meu reconhecimento àqueles que viabilizaram a realização desse trabalho.

Aos professores do curso de Pós Graduação do qual tive a oportunidade de aprofundar os meus conhecimentos em ciências agrárias, em especial, ao professor Marcos Silveira Bernades, orientador da tese, pesquisador do tema, que compartilhou comigo os desafios desse trabalho.

Aos integrantes da banca examinadora da tese, e em particular a Dra Marilene Bovi, pelas valiosas observações e sugestões fornecidas ao longo do registro dos trabalhos.

A Faculdade de Ciências Agrárias do Pará (FCAP) e ao Departamento de Fitotecnia, principalmente ao Diretor Dr. Manoel Malheiros Tourinho e ao Prof. Pedro Gazel, que proporcionaram as condições para realizar esse estudo.

A FAPESP, pelo financiamento do projeto viabilizando a realização da pesquisa 


\section{SUMÁRIO}

Página

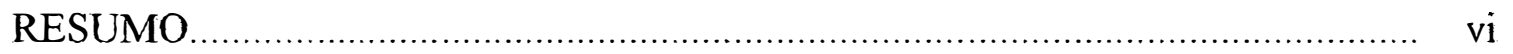

SUMMARY

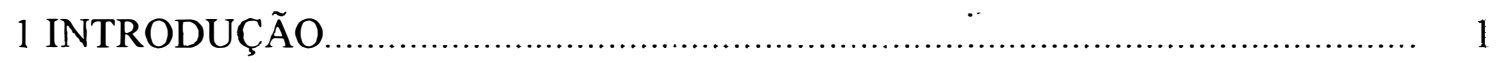

2 REVISÃO DE LITERATURA ................................................................ 3

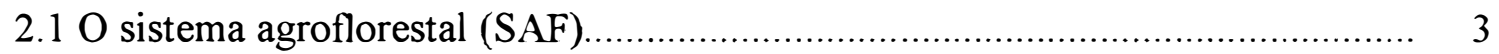

2.2 Competição por luz e uso eficiente da radiação (RUE) .................................... 4

2.3 Importância econômica e ecológica do açaizeiro.............................................. 6

2.4 A luz como fator ecológico importante no crescimento e estabelecimento das 9 palmeiras.

3 MATERIAL E MÉTODOS ...................................................................... 17

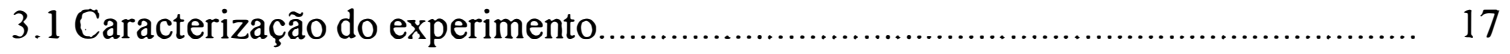

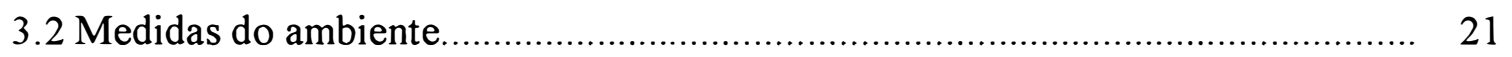

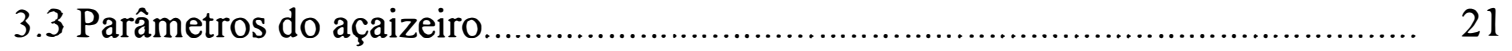

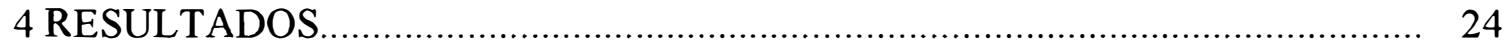

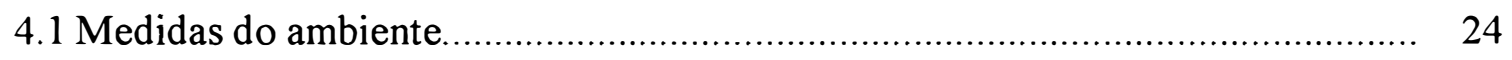

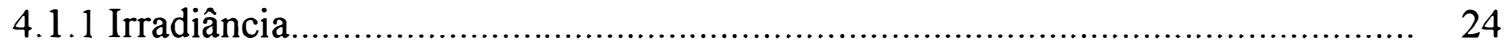

4.1.2 Temperatura do ar e do solo e déficit de pressão de vapor do ar..................... 28

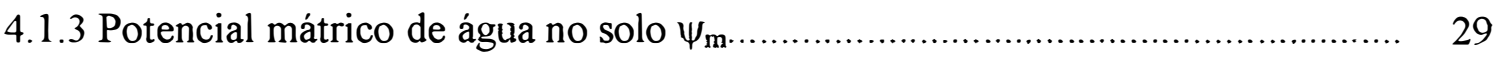

4.1.4 Evapotranspiração de referência............................................................... 29

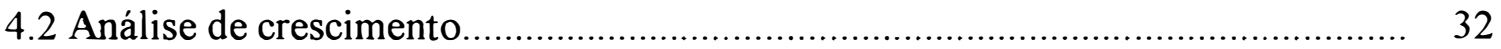

4.2.1 Massa seca da parte aérea, área foliar, altura e diâmetro das plantas.............. 32

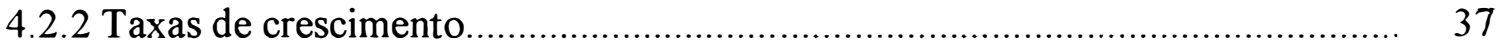


4.2.2.1 Taxa de crescimento absoluto (TCA) ……......................................... 37

4.2.2.2 Taxa de crescimento relativo (TCR) ................................................... 37

4.2.2.3 Taxa de assimilação líquida(TAL) ......................................................... 38

4.2.2.4 Razão de área foliar (RAF) ........................................................... 38

4.2.3 Eficiência de uso da radiação disponível (RUEd)......................................... 41

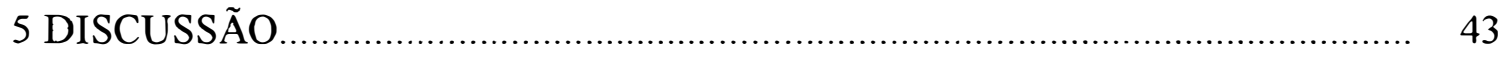

5.1 Matéria seca da parte aérea, área foliar, altura e diâmetro das plantas................ 43

5.2 Análise do crescimento .......................................................................... 45

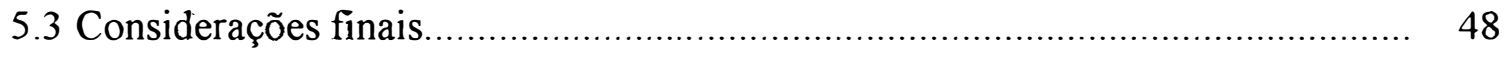

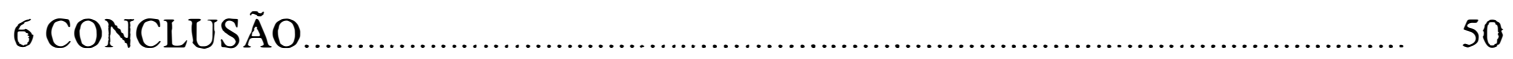

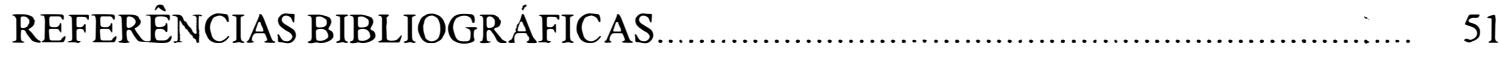




\title{
RADIAÇÃO E CRESCIMENTO DE PLANTAS JOVENS DE AÇAÍ EM SISTEMAS AGROFLORESTAIS
}

\author{
Autora: LEILA SOBRAL SAMPAIO
}

Orientador: Prof. Dr. MARCOS SILVEIRA BERNARDES

\section{RESUMO}

$\mathrm{O}$ açaizeiro (Euterpe oleracea Mart.), na fase juvenil, foi estudado sob diferentes sistemas agroflorestais, em Piracicaba - SP $\left(22^{\circ} 42^{\prime} 30^{\prime \prime} \mathrm{S}, 47^{\circ} 38^{\prime} 00^{\prime \prime} \mathrm{W}\right.$, altitude de 531 m). Os açaizeiro cresceram em sistemas agroflorestais sob dossel de cacaueiro, guarantã e leucena (CAC), sob seringueira (SER), e em fileiras na transeção distanciadas em 1,5m, 5,5m, 9,5m, 15,5m, 22,5m e 33,5m da borda da seringueira, irrigadas por aspersão convencional com uma lâmina média de $3 \mathrm{~mm}$ nos dias sem chuva. Foram medidas a irradiância disponível para o açaizeiro, a temperatura do ar e do solo, e a tensão de água no solo. A irradiância relativa (Ir) disponível para o açaizeiro foi de 6-10\% no CAC, 18$39 \%$ no SER, $28-33 \%$ à $1,5 \mathrm{~m}, 52-54 \%$ à $5,5 \mathrm{~m}, 62-70 \%$ à $9,5 \mathrm{~m}, 78-86 \%$ à $15,5 \mathrm{~m}, 85-$ $93 \%$ à $23,5 \mathrm{~m}$ e de $88-97 \%$ à $33,5 \mathrm{~m}$. Crescimento da massa seca acima do solo (M), área foliar (AF), diâmetro da haste principal (D) e altura da planta $(\mathrm{H})$, taxa de crescimento absoluto e relativo (TCA e TCR), razão de área foliar (RAF), taxa de assimilação líquida (TAL) e uso eficiente da radiação disponível (RUEd), foram avaliados em função da disponibilidade de irradiância, em três períodos de crescimento: P1- novembro de 2001 à maio de 2002; P2 - maio a novembro de 2002 ; e P3-novembro de 2002 a maio de 2003. Valores máximos de M, AF, D e H de $327,32 \mathrm{~g}, 1,12 \mathrm{~m}^{2}, 0,031 \mathrm{~m}$ e $0,45 \mathrm{~m}$ e 792,05 g, $2,85 \mathrm{~m}^{2}, 0,056 \mathrm{~m}$ e $0,59 \mathrm{~m}$, ocorreram entre a irradiância relativa de $52 \%$ a $67 \%$ e $60 \%$ a 89 \%, P2 e P3. As diferenças de M, AF, D e $\mathrm{H}$ entre tratamentos foram desprezíveis no 
P1. TCA, TCR, TAL e RUE aumentaram com a idade para os sistemas acima de $10 \%$ de Ir. As plantas que cresceram sob Ir maior de $10 \%$ e menor que $80 \%$ apresentaram menor RAF e maior TCA, TCR, TAL e RUEd. O sombreamento foi importante no estabelecimento do açaí após plantio. Entretanto o seu excesso foi limitante para o crescimento das plantas. $\mathrm{O}$ açaizeiro mostrou uma grande plasticidade no crescimento $\mathrm{e}$ na eficiência do uso da radiação disponível em função das intensidades de irradiância. $\mathrm{O}$ açaizeiro apresentou a capacidade de adaptar-se a uma faixa grande de irradiância que vai desde ao intenso sombreamento até a intensidades altas de irradiância. O crescimento do açaizeiro aumentou com o incremento da disponibilidade de irradiância até um ótimo que ocorre numa irradiância relativa menor que $80 \%$. A irradiância relativa ótima para o crescimento aumentou com incremento da idade dos açaizeiros.

Palavras-chave: Agrossilvicultura, seringueira, cacau, leucena, sombreamento. 


\title{
RADIATION AND GROWTH OF YOUNG ASSAI PALMS IN AGROFORESTRY SYSTEMS
}

\author{
Author: LEILA SOBRAL SAMPAIO
}

Adviser: Prof. Dr. MARCOS SILVEIRA BERNARDES

\section{SUMMARY}

Juvenile assai palms (Euterpe oleracea Mart.) were studied under different

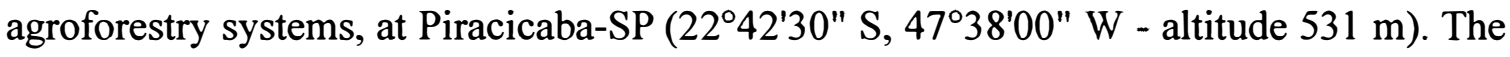
assai grew in agroforestry systems under cocoa, guarantã and Leucaena trees (CAC), under rubber trees (SER), and in rows 1,5m, 5,5m, 9,5m, 15,5m, 22,5m and 33, aside from the border of a rubber alley, with $3 \mathrm{~mm}$ sprinkler irrigation every non rainy day. It was measured the available irradiance for the assai, the air and soil temperature and the water tension in the soil. Relative irradiance (Ir) available to the assai was $6-10 \%$ at $\mathrm{CAC}, 18-39 \%$ at SER, $28-33 \%$ at $1,5 \mathrm{~m}, 52-54 \%$ at $5,5 \mathrm{~m}, 62-70 \%$ at $9,5 \mathrm{~m}, 78-86 \%$ at $15,5 \mathrm{~m}, 85-93 \%$ at $23,5 \mathrm{~m}$ and $88-97 \%$ at $33,5 \mathrm{~m}$. Above ground dry matter (M), leaf area $(A F)$, trunk diameter $(D)$, plant height $(\mathrm{H})$, absolute (TCA) and relative (TCR) growth rate, leaf area ratio (RAF), net assimilation rate (TAL) and radiation use efficiency (RUEd), were evaluated in function of the available irradiance, in three growth periods: P1 - November 2001 to May 2002; P2 - May to November of 2002; and P3-November 2002 to May 2003. Maximum values of M, LA, D and $\mathrm{H}$ of $327.32 \mathrm{~g}, 1.12 \mathrm{~m}^{2}, 0.031 \mathrm{~m}$ and $0.45 \mathrm{~m}$ and $792.05 \mathrm{~g}, 2.85 \mathrm{~m}^{2}, 0.056 \mathrm{~m}$ and $0.59 \mathrm{~m}$, occurred ion the range of relative irradiance of $52 \%$ to $67 \%$ and $60 \%$ to $89 \%$, in the P2 and P3, respectively. The differences of DM, LA, D and $\mathrm{H}$ were negligible between treatments in the P1. TCA, TCR, TAL e RUEd increased with the age for the systems with Ir larger than $10 \%$ and smaller than $10 \%$. Plants under Ir lower than $10 \%$ and higher than $80 \%$, presented 
the smallest RAF and largest TCA, TCR, TAL and RUEd. Shading was important for the plant establishment after planting. However, excessive shading limited plant growth. The assai palms showed large plasticity for growth and radiation use efficiency in function of the irradiation intensities. The assai palm presented the capacity to adapt to a large range of irradiance from strong shading to high irradiance intensities. Growth of assai palm increase with augmentation of the available irradiance till an optimum that occurs at a relative irradiance smaller than $80 \%$. An optimum relative irradiance increases with the age of assai palms.

Key-words: Agroforestry, rubber, cacao, Leucaena, shade. 


\section{INTRODUÇÃO}

A combinação de espécies é uma forma sustentada de uso do solo nos trópicos, com grandes vantagens na utilização dos recursos como água, luz e nutrientes e na manutenção da produtividade. A utilização mais eficiente dos recursos pelas espécies em combinação é fundamental no esforço de restaurar florestas e no uso sustentado da terra. Neste aspecto, incluem-se os reflorestamentos com espécies nativas, os enriquecimentos de florestas secundárias e os sistemas agroflorestais (Haggar \& Ewel, 1995).

Nos sistemas naturais ou manejados onde há convivência simultânea de diversas espécies a luz é um dos recursos de maior competição e pode ser limitante a espécies que crescem nos estratos mais inferiores. Foram feitas numerosas tentativas para reunir atributos funcionais das espécies a um gradiente de tolerância de sombra. O consenso atual é que a tolerância à sombra é o resultado da interação de várias características que contribuem para a sobrevivência das plantas a níveis baixos de irradiância. Isso envolve o tamanho e a eficiência do aparato de captação de energia luminosa, a capacidade de conversão dessa energia em carboidrato, o transporte e metabolismo desse carboidrato nas diversas partes da planta (Givnish, 1988; Messier et al., 1999; Walters \& Reich, 1999).

As palmeiras, devido a sua vasta utilização e adaptação a vários ambientes, têm sido muito utilizadas em sistemas agroflorestais. Haggar \& Ewel (1997) destacam o uso das palmeiras, dentro do grupo das monocotiledôneas, nos sistemas de policultivos. Os autores ressaltam a habilidade de alocação de recursos para estruturas de captura de luz (área foliar) e água (raízes finas) das espécies Euterpe oleracea Mart. e Heliconia imbricata Baker, aos três anos de idade, em sub-bosque. Estudos com a palmeira Euterpe edulis Mart., aos dois anos de idade, destacam a capacidade de adaptação da espécie tanto ao aumento quanto à diminuição da radiação através de alterações 
morfofisiológicas, com alguma limitação a altos níveis de radiação (Paulilo, 2000). Vários desses atributos podem mudar com a idade da planta, normalmente resultando em uma diminuição aparente de tolerância à sombra em função do aumento da idade e do tamanho (Givnish, 1988; Messier et al., 1999).

A mudança na eficiência do uso da radiação (RUE - $\mathrm{g} \mathrm{MJ}^{-1}$ ), isto é, na capacidade de crescimento em função da quantidade de energia luminosa interceptada, é uma das principais respostas de adaptação das plantas a baixa intensidade de irradiância. As primeiras análises da relação entre o acúmulo de massa seca das culturas e a radiação interceptada foram realizadas por Monteith (1977), que concluiu que esse coeficiente, para a maioria das culturas, está em 1,4 $\mathrm{g} \mathrm{MJ}^{-1}$. No entanto, tem sido verificado que esse valor é bastante variável entre e dentre espécies, e em condições de ambientes diversos (Sinclair \& Muchow, 1999). A quantidade e a qualidade da radiação são importantes na análise da RUE. Para soja e milho a RUE aumentou em $0,35 \mathrm{~g} \mathrm{MJ}^{-1}$ com o aumento da fração difusa de 15 para $30 \%$ e reduziu linearmente com aumento da radiação total (Sinclair et al., 1992). Os autores consideram que em ambientes em que a fração difusa da radiação incidente é maior, seria esperado aumento na RUE comparado a ambientes em que predomina a fração direta.

É conhecida a importância da luz como fator limitante para o crescimento e a produção das plantas. Entretanto, a quantificação do seu efeito permanece pouco estudada ao longo da ontogênese. Um método simples e eficaz para verificar o efeito da irradiância é medir a produção de biomassa na transeção da interface árvore-cultura (Ong \& Huxley, 1996). Outro método, visando estabelecer as melhores intensidades de luz para as plantas, seria o seu cultivo sob diferentes tipos de copas.

O presente estudo tem por objetivo avaliar e quantificar o crescimento de plantas jovens da palmeira açai (Euterpe oleracea Mart.) em diferentes sistemas agroflorestais em função da disponibilidade de luz, testando as seguintes hipóteses: o crescimento do açaizeiro será melhor em sistemas com maior disponibilidade de luz; o açaizeiro apresenta a habilidade de adaptar-se a ambientes com diferentes irradiâncias disponiveis; a tolerância do açaizeiro ao sombreamento reduz-se com a idade da planta; a irradiância que propicia o máximo crescimento aumenta com a idade. 


\section{REVISÃO DE LITERATURA}

\subsection{Sistema agroflorestal (SAF)}

O SAF é um sistema de uso da terra no qual as árvores crescem em associação com outras culturas perenes ou anuais, ou com animais domésticos, em vários arranjos no espaço e no tempo, favorecendo interações ecológicas e econômicas entre as árvores e as outras culturas, gerando vantagens comparativas aos outros sistemas de agricultura (Nair, 1989; Young, 1997). Os SAFs vêm sendo apontados como opção preferencial de uso da terra, por terem elevado potencial para aumentar a sustentabilidade do sistema, quanto a aspectos agronômicos, sociais, econômicos e ecológicos. A combinação de culturas com espécies arbóreas favorecem a proteção do solo e a manutenção da fertilidade (Young, 1997; Baumer, 1990). Os SAFs com seringueiras maduras são equivalentes aos sistemas naturais de florestas tropicais úmidas. Os níveis de dióxido de carbono, oxigênio e água, reciclados nesses seringais são aproximadamente iguais aos encontrados nas florestas tropicais (Goldthorpe, 1996; Bernardes et al., 2000).

Há cada vez mais, maiores evidências de que os SAFs têm um grande potencial por melhorar as propriedades do solo, tanto químicas quanto físicas, porém o maior desafio está em traduzir tais melhorias em aumento da produtividade para as culturas (Ong et al., 1996). O entendimento dos processos e mecanismos envolvidos na captura dos recursos água, luz e nutrientes, e no seu uso e suas interações é de fundamental importância na maximização de interações positivas e na minimização das interações negativas (Willey \& Reddy, 1981; Ong et al., 1996).

As interações entre os componentes arbóreos e não arbóreos são afetadas principalmente pelo microclima e pelo solo, onde as principais interações negativas são: sombreamento e competição por água e por nutrientes (Young, 1997). 
Apesar de muito divulgados os benefícios ecológicos e ambientais que os SAFs poderiam trazer, é ainda dificil quantificar a dimensão das modificações micrometeorológicas e de suas implicações em seus componentes e no ambiente, uma vez que poucos são os trabalhos que têm monitorado variáveis biofisicas em SAF (Sá, 1994).

O princípio da complementaridade para o uso dos recursos disponíveis, água, luz e nutrientes, não totalmente explorados por uma única espécie é considerada chave na combinação de árvores com culturas (Cannell et al., 1996). As combinações de árvores que têm maior alocação para estrutura de suporte com outras que têm grande alocação para estruturas de captura de recursos garantem maior produtividade ao sistema (Haggar \& Ewel, 1997).

De acordo com Ong et al. (1996), o estudo dos princípios da captação de recursos em SAF é útil na análise de desempenho das culturas envolvidas sob várias condições de clima e manejo. Haggar \& Ewel (1997) avaliaram, positivamente, o desempenho das palmeiras na interceptação de luz e na captura de água e nutrientes. Estudos com palmeiras em combinação com árvores relatam o potencial de sua utilização em SAFs (Bovi et al., 1990; Haggar \& Ewel,1997; Kalil Filho et al., 1998; Bernardes et al., 2000).

\subsection{Competição por luz e eficiente do uso da radiação}

Quando duas espécies são plantadas juntas é inevitável a competição de recursos para o crescimento. A produtividade de cada componente depende de sua habilidade de captura de luz, água e nutrientes e sua resposta a mudanças no microclima. $\mathrm{O}$ entendimento de como os SAFs utilizam os recursos é fundamental para o estabelecimento de combinações de espécies, arranjo da plantação, densidade de plantio e manejo adequado para diferentes localidades. A luz é um importante fator de competição nos sistemas enquanto a água e os nutrientes estão geralmente disponíveis. Nesses termos, é possível aumentar a produtividade usando-se uma mistura de espécies; as espécies componentes captam mais recursos disponíveis ou usam-nos com maior eficiência para o crescimento do que nos monocultivos (Ong \& Huxley, 1996). 
O conceito da captura e uso da radiação de Monteith (1977) tem sido importante na interpretação de resultados experimentais, no entendimento das interações genótipo e ambiente e na determinação de mecanismos responsáveis pela produção em sistemas agroflorestais ou de consórcio entre culturas anuais. A captura e o uso da radiação na produção da massa seca consiste na fração da radiação fotossinteticamente ativa incidente que é interceptada pelas plantas e a eficiência com que é usada para produção da massa seca. É estimada, preferencialmente, através da inclinação linear entre a produção de massa seca e radiação interceptada (Black \& Ong, 2000; Sinclair \& Muchow, 1999).

Numerosos estudos de culturas anuais e espécies perenes têm mostrado a existência de correlação entre produção de massa seca e radiação interceptada. Howard et al. (1995) estudaram as interações de luz e água em sistemas agroflorestais envolvendo leucena e milho. $\mathrm{O}$ total de radiação interceptada foi maior no sistema leucena-milho, $413 \mathrm{MJ} \mathrm{m}^{-2}$ comparado com as espécies isoladas, $258 \mathrm{MJ} \mathrm{m}^{-2}$ (milho) e $327 \mathrm{MJ} \mathrm{m}^{-2}$ (leucena). Estreita correlação foi encontrada entre a produção de massa seca e radiação interceptada.

Estudos mais recentes mostram que a eficiência do uso da radiação mantém-se relativamente constante entre as espécies de mesmo gnupo metabólico: $1,95 \mathrm{~g} \mathrm{MJ}^{-1}$ para espécies $\mathrm{C}_{3}$ e 2,5 $\mathrm{g} \mathrm{MJ}^{-1}$ para espécies $\mathrm{C}_{4}$. A estabilidade do uso eficiente é somente observada em condições de ausência de estresses, uma vez que nessas condições o valor decresce (Lemaire, 1995, Demetries-Shah et al.,1992).

Sinclair \& Muchow (1999), com base em análise teórica e experimental, mostram que o valor da eficiência do uso da radiação não é uma constante universal estando essa quantitativamente relacionada às características da planta e às condições ambientais.

Estudos teóricos apontam a importância da taxa fotossintética da folha na eficiência do uso da radiação (RUE). As plantas $\mathrm{C}_{4}$ tendem a ter valores mais altos que as plantas $\mathrm{C}_{3}$, entretanto os valores em espécies $\mathrm{C}_{4}$ são variáveis. Cana-de-açúcar apresenta alta RUE $\left(2,0 \mathrm{~g} \mathrm{MJ}^{-1}\right)$ comparada com outras espécies $\mathrm{C}_{4}$, como o milho e o sorgo, de 1,5 a 1,7 $\mathrm{g} \mathrm{MJ}^{-1}$. Inthapan \& Fukai (1988) comparam a RUE do sorgo e milho 
com a do arroz e mostraram que as duas primeiras foram equivalentes, porém $42 \%$ mais eficientes. Diferenças experimentais também ocorrem em plantas $C_{3}$. A batata tem valores de RUE substancialmente maiores que outras plantas $C_{3}$, na faixa de 1,6 a $1,75 \mathrm{~g}$ $\mathrm{MJ}^{-1}$. Deste modo, a variação da RUE entre as espécies é devida não só a capacidade fotossintética, mas aos componentes bioquímicos dos produtos das plantas que determinam diferentes demandas energéticas por unidade de massa produzida. $O$ déficit hídrico, o conteúdo de nitrogênio na folha, a temperatura e outros fatores que provocam alterações na capacidade fotossintética durante o ciclo da planta também podem causar mudanças diretas na RUE (Sinclair \& Muchow, 1999).

$\mathrm{O}$ ambiente pode ter importantes conseqüências sobre a RUE além do efeito direto sobre a fotossíntese. As variações da RUE podem ser conseqüência das diferentes intensidades de radiação ou da proporção da radiação direta e difusa entre diversos locais. Hammer \& Wright (1994) concluíram a partir de análise teórica que a intensidade de radiação de um dia nublado, comparado com um dia claro resulta no aumento de 0,4 g $M J^{-1}$ da RUE.

Evidências de vários estudos experimentais indicam que o ambiente de radiação afeta os valores da RUE. Horie \& Sakuratani (1985) aplicaram o sombreamento de $46 \mathrm{e}$ $72 \%$ em arroz, como resultado a RUE aumentou de $1,26 \mathrm{~g} \mathrm{MJ}^{-1}$ no tratamento não sombreado para 1,66 $\mathrm{g} \mathrm{MJ}^{-1}$ com $46 \%$ de sombra; e 1,98 $\mathrm{g} \mathrm{MJ}^{1}$ com $72 \%$ de sombra. Em um experimento com amendoim (Stirling et al., 1990), o sombreamento da cultura em $75 \%$ no estágio reprodutivo resultou no aumento da RUE de $0,98 \mathrm{~g} \mathrm{MJ}^{-1}$ para 2,36 $\mathrm{g} \mathrm{MJ}^{-}$

${ }^{1}$. Nesses dois casos, a redução da irradiância causou o aumento da RUE. Deste modo a RUE pode ser considerada um importante indicador na escolha de plantas, arranjamento e composições de sistemas agroflorestais.

\subsection{Importância econômica e ecológica do açaizeiro}

O açaizeiro (Euterpe oleracea Mart.) é uma das 180 espécies de palmeiras de grande importância econômica da flora Amazônica. Habita preferencialmente ambientes alagados no leste amazônico e está distribuído em todos os extratos da várzea, várzea alta e várzea baixa, e igapó. Apresenta a maior densidade populacional nas áreas de 
maior influência das marés. A adaptabilidade da espécie a ambientes inundados (Menezes Neto,1994; Pelacani et al.,1995; Carvalho et al., 1998) justifica a sua forte presença nas bordas de rios e igarapés, e seu domínio nas várzeas baixas e igapós, onde não sofre competição por luz com outras espécies.

$\mathrm{O}$ açaizeiro caracteriza-se por apresentar porte arbóreo e reto, altura acima de $12 \mathrm{~m}$, e capacidade de emissão de vários caules a partir da base do caule da planta mãe, formando as touceiras. Segundo Cavalcante (1974), citado por Kahn \& Granville (1992), numa touceira pode ocorrer mais de 25 estipes. O sistema radicular é pouco profundo, constituído por raizes aéreas, pneumatóforos e raizes adventíceas. $\mathrm{O}$ desenvolvimento de raizes com geotropismo negativo é uma característica da espécie em solos inundados (Granville, 1974, Sampaio, 1998).

Dos frutos, produz-se uma bebida popular e um saboroso sorvete a partir do mesocarpo. O açai, denominação popular para a bebida e para a espécie, é um componente importante na dieta alimentar, e um importante produto no comércio regional. Atualmente, a polpa de açaí ganha espaço no mercado nacional de polpa de frutas, apresentando grande demanda fora da região tradicional de consumo. Entretanto, a principal atividade de exploração do açaizeiro é o palmito.

Outras partes da palmeira são largamente utilizadas; as folhas são usadas na cobertura de casas, como material de construção, no preparo artesanal de cestos, além da qualidade das fibras e da celulose; o tronco é utilizado como material de construção e fabricação caseira de cola; e as raizes têm propriedades medicinais indicadas para controle de verminoses (Anderson, 1988).

A Euterpe oleracea é considerada uma das espécies chaves das várzeas do estuário Amazônico (Anderson et al., 1985; Anderson, 1988). O manejo de populações nativas de açaizeiro é uma alternativa viável de manejo da terra e requer alto grau de integração na exploração do produto, fruto ou palmito, de modo a manter o potencial do sistema. O rendimento médio anual da exploração da palmeira açaí pode chegar até US\$4.266-6.930 por ha de quintais agroflorestais (Muñiz-Miret et al., 1996).

A extração do palmito do açaizeiro é responsável por $90 \%$ do palmito comercializado no Brasil. A alta densidade dos açaizeiros em áreas de floresta do 
estuário Amazônico $\left(25.000 \mathrm{~km}^{2}\right)$ e a característica multicaulinar permitem a remoção do palmito ano após ano sem matar a planta, o que torna a espécie ideal para perpetuação da extração do palmito. Mas, desde os anos 80 vários indicadores apontam que a exploração do palmito, nos níveis atuais não seria sustentada. Por exemplo, o tamanho médio do palmito hoje é menor que há 20 anos, o que indica que plantas menores estão sendo cortadas. Há também, atualmente, menos fábricas operando, onde a exploração foi muito intensa no passado, o que sugere que o estoque diminuiu ao longo do tempo. Enquanto não há evidências de que a palmeira açaí não está sendo ameaçada como espécie, estes e outros indicadores de pressão sobre o recurso mostram dificuldades potenciais para suprir a necessidade da indústria de palmito no futuro. Como conseqüência dessa realidade, o palmito brasileiro, visto como um produto sem nenhuma padronização, controle de qualidade ou preocupação com o ambiente, tem perdido espaço no mercado internacional (Pollak et al., 1996).

A clandestinidade do mercado do palmito no Brasil ainda é um grande problema para a espécie. As estatísticas oficiais apontam uma produção de 20 mil toneladas anuais, mas acredita-se que esta ultrapasse a 180 mil toneladas, cifra que nos coloca como o maior produtor e consumidor mundial de palmito. Estima-se que o mercado interno seja pelo menos seis vezes maior que o mercado internacional, correspondendo, portanto a 180 milhões de dólares, visto que o preço interno e externo são praticamente os mesmos (FNP, 1999).

A exploração irracional das reservas, a demanda crescente do produto e os preços altos, tem estimulado o plantio comercial de espécies capazes de oferecer alta produtividade a custos viáveis e palmitos de qualidade superior. A principal delas é o açaizeiro, que já domina grande parte do mercado, apresenta as vantagens de produzir perfilhos, ao contrário da jussara que morre com a exploração do palmito; tem adaptação a ambientes alagados, podendo ser alternativa na formação de matas ciliares e oferece alternativa de produção de fruto para comercialização da polpa. A possibilidade de utilização dessa espécie em plantios comerciais, diminuindo a pressão extrativista, depende do desenvolvimento de tecnologia apropriada para esta finalidade. A utilização da espécie em florestas de várzeas explorada ou quintais constituem sistemas muito 
semelhantes a SAFs, onde o ribeirinho determina o arranjo espacial das espécies, altera a densidade de populações conforme seu interesse, e retira da floresta o seu sustento econômico e alimentar, desempenhando grande papel no processo de domesticação das espécies.

\subsection{A luz como fator ecológico importante no crescimento e estabelecimento das palmeiras}

Devido ao seu valor econômico e alimentar, o açaizeiro é a espécie que mais se destaca nos quintais agroflorestais (Rosa et al., 1998). O manejo do açaizeiro nestas áreas é dado principalmente em função da luz. Eliminam-se as espécies de maior porte e faz-se o desbaste dos estipes maiores na própria touceira, de acordo com a exploração pretendida, se de fruto ou de palmito (Nogueira et al., 1995). Estudos realizados por Jardim \& Rombold (1994) com desbaste seletivo das touceiras em áreas exploradas de açaizais nativos, verificaram um aumento de $30 \%$ na produção de frutos.

Os trabalhos são conclusivos quanto à importância da luz na escolha de sistemas de produção para palmeiras produtoras de palmito. Palmeiras encontradas a céu aberto têm o seu crescimento diminuído em altura e aumentado em diâmetro, possibilitando assim, maior rendimento da matéria-prima para conserva e reduzindo o tempo para o corte. Isso prova que o palmito, após certa idade, deve receber maior luminosidade e, em certos casos, até radiação direta (Pedrosa Macedo, 1973). No que se refere à fase inicial de crescimento, o sombreamento e o alto teor de umidade no solo e no ar têm grande influência na sobrevivência e no desenvolvimento da jussara (Euterpe edulis), em função de seu caráter umbrófilo (Yamazoe et al., 1986; Reis et al., 1987). No estudo de Yamazoe et al. (1986), a melhor intensidade luminosa para o desenvolvimento da jussara sob Pinus pinaster variou de 20 a $60 \%$; a $80 \%$, constataram menor percentagem de sobrevivência. Pinheiro et al. (1988), chegaram a conclusões semelhantes, em plantio de juçara sob Pinus kesiya. Estudos mais recentes relatam que o sombreamento de 50\% é o ideal para a espécie na fase inicial de crescimento (Caldeira et al., 1996; Nodari et al., 1999). 
Embora pouco estudadas, as palmeiras diferenciam-se em nichos, principalmente em termos de exigências de luz e de preferências edafo-topográficas. Svenning (2001) discutiu a importância da luz no estabelecimento das palmeiras em diversos ambientes de luz no estrato da floresta e denominou as palmeiras em palmeiras de sub-bosque, menos de $5 \mathrm{~m}$ de altura, palmeiras de bosque, com altura entre $5 \mathrm{~m}$ e $14 \mathrm{~m}$, e palmeiras de dossel, com altura acima de $15 \mathrm{~m}$.

As palmeiras adaptam-se fisiologicamente e anatomicamente às condições de luz dos ambientes (Hogan, 1988; Broschat et al., 1989), podem ser altamente tolerante a sombra, requerer sombra ou até altas intensidades de luz. Somado a esse fato, a resposta à luz parece não ser uma característica estática para as palmeiras (Svenning, 2001).

A tolerância à sombra geralmente declina durante a ontogênese, com aumento desproporcional da folha e da altura da planta (Givnish, 1999). Isto acontece nas palmeiras de sub-bosque Geonoma cuneata, G. congesta, e Asterogyne martiana no qual a relação da área foliar total e a altura declinam com o aumento da altura da planta, e a capacidade de interceptação da luz aumenta a uma taxa mais lenta (Chazdon, 1985). A proporção de biomassa de folhas vivas diminui em relação à biomassa total com o crescimento em duas outras palmeiras de sub-bosque (Ataroff \& Schwarzkopf, 1994). As palmeiras de dossel também parecem tornar-se decrescentemente tolerantes a sombra com o crescimento (Granville, 1992), embora em diferentes proporções (Svenning, 1999). Isso não é só devido ao crescimento em altura, mas também a mudanças na arquitetura da copa. Assim, Iriartea deltoidea a partir de $10 \mathrm{~m}$ de altura começa a produzir folhas mais fechadas (Givnish, 1999). Em suma, é provável que a tolerância à sombra dentro da espécie diminua com o crescimento das palmeiras, embora mudanças fisiológicas (Woodward, 1990) possam modificar ou até mesmo inverter esse padrão em alguma espécie. Certamente, a dinâmica de resposta de uma determinada espécie de palmeira em relação à disponibilidade de luz precisa ser avaliada sobre a sua ontogênese por inteiro. 
As comunidades de palmeiras em ecossistemas naturais são formadas em função da arquitetura e dinâmica da floresta. $\mathrm{O}$ desenvolvimento de palmeiras de porte alto requer alta intensidade luminosa o que depende diretamente da abertura do dossel (Kahn \& Granville,1992). Kahn (1986) sugeriu que palmeiras de porte alto dependem de grandes aberturas do dossel para atingir a fase adulta devido ao seu alto requerimento de luz no desenvolvimento do caule (Figura 1).

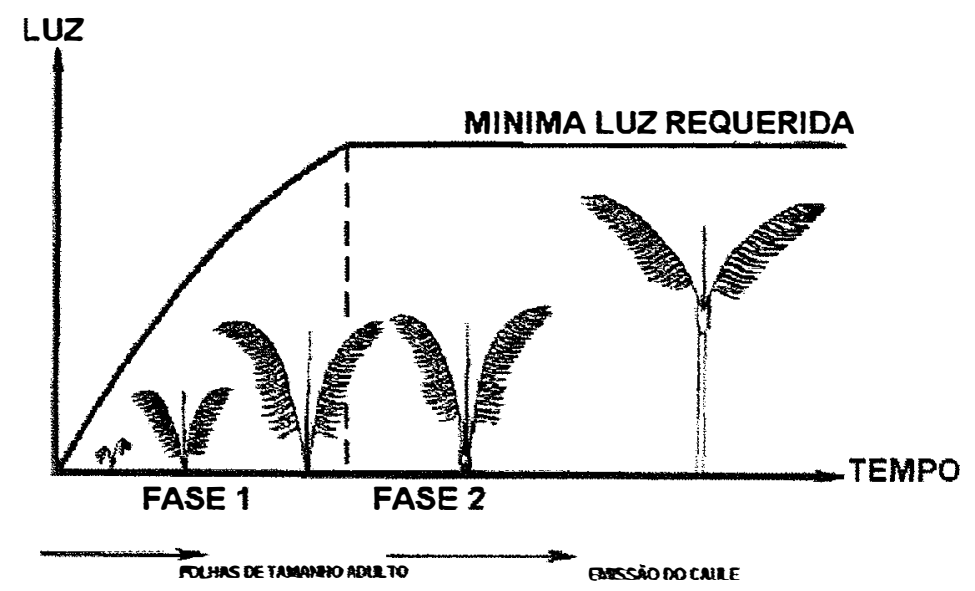

Figura 1- Crescimento de palmeiras arborescentes e requerimento de luz. A intensidade de luz requerida aumenta com a idade da planta. Com a folha de tamanho adulto, a palmeira necessita de uma intensidade de luz consistentemente alto para emissão do caule.(Fonte: Kahn, 1986)

A disponibilidade de luz é importante no crescimento e no estabelecimento das palmeiras, porém tal efeito é altamente variável. A baixa disponibilidade de luz do subbosque de uma floresta úmida seria um agente de mortalidade para as palmeiras (Enright \& Watson, 1992), porém há carência de evidências experimentais. Ao contrário, há muitas comprovações de danos e mortalidade causada pela queda de árvores, e aumento na disponibilidade de luz. $\mathrm{O}$ dano parece ser resultado de quatro fatores: solarização (Salisbury \& Ross, 1992), herbívoros, escombro de árvores, e invasão por plantas daninhas.

A solarização é a inibição da fotossíntese e destruição de cloroplastos (Salisbury \& Ross, 1992), que pode ser causado pela intensidade alta de luz com a abertura do 
dossel nas florestas. O estresse hídrico e a alta intensidade de luz atuam sinergicamente produzindo a solarização (Araus \& Hogan, 1994). Os danos causados pelas altas intensidades de luz podem ser mais importantes onde há uma estação seca definida e podem variar dependendo das condições edáficas ou topográficas do local. As palmeiras de sub-bosque adaptadas à sombra são particularmente suscetíveis à solarização, devido em parte à arquitetura de sua copa que maximiza a interceptação da luz e do calor e também à anatomia da folha adaptada à sombra (Chazdon, 1985; Granville, 1992). Por conseguinte, as plântulas de Geonoma congesta, G. cuneata, e Asterogyne martiana são fortemente solarizadas a $25,5 \%$ de irradiância (Chazdon, 1986a), e as plântulas de Geonoma macrostachys var. macrostachys experimentaram solarização severa quando transplantadas no centro de uma clareira de $200 \mathrm{~m}^{2}$ (Svenning, 2001). Muitas palmeiras de sub-bosque na Malásia também parecem ser altamente sensíveis à solarização. Embora as palmeiras de dossel sejam mais tolerantes, a sensibilidade à solarização é bastante variável (Araus \& Hogan, 1994).

Na Costa Rica, plântulas de Iriartea deltóidea, I. gigantea, Socratea exorrhiza e S. durissima declinam sob um dossel fechado, mas crescem quando expostas a uma pequena abertura; as plantas juvenis dessa espécie parecem mostrar crescimento positivo mesmo sob dossel fechado (Vandermeer et al., 1974). Welfia regia e $W$. georgii, na fase de plântula e juvenil, declinam sob um dossel fechado, porém crescem quando, expostas a uma menor ou maior abertura (Vandermeer et al., 1974). No Panamá, palmeiras de oito anos de idade de Socratea exorrhiza tiveram crescimento em altura de aproximadamente $75 \mathrm{~cm}$ a $1 \%$ de luz total, enquanto que palmeiras juvenis de Attalea butyracea e Scheelea zonensis, de idade similar tiveram alcançado somente $25 \mathrm{~cm}$. Ambas espécies têm crescimento maior que $4 \mathrm{~m}$ a $70 \%$ de luz total (Araus \& Hogan, 1994).

Mesmo as palmeiras de sub-bosque muito tolerantes a baixa intensidade de luz (Geonoma congesta, G. cuneata, Asterogyne martiana) são limitadas pelo sombreamento. $\mathrm{O}$ seu crescimento está linearmente relacionado à disponibilidade de luz difusa de 0,1 a $1,2 \mathrm{~mol} \mathrm{~m}^{-2}$ por dia dentro da faixa da radiação fotossinteticamente ativa, sendo somente positivo a valores maiores de $0,20 \mathrm{~mol} \mathrm{~m}^{-2}$ por dia, o que representa, 
aproximadamente, 1,0\% da luz natural (Chazdon, 1986a). Deste modo, o crescimento é esperado sob extrema de abertura de dossel em relação a condições de sub-bosque fechado (Chazdon, 1986b).

A limitaçao do crescimento pela baixa intensidade luminosa ocorre em plântulas e em indivíduos maiores. Em Geonoma macrostachys var. macrostachys, o crescimento aumenta com a iluminação da coroa, crescente a partir de baixa, média e alta exposição de luz; e em baixa iluminação as plântulas e jovens palmeiras mantêm em média zero ou crescimento positivo (Svenning, 2001).

A produção de folhas e de perfilhos também aumenta com a disponibilidade de luz (Steven et al., 1987). A produção anual de folha aumentou entre as palmeiras de bosque, Attalea butyracea, Scheelea zonensis, Oenocarpus mapora e O. panamanus com aumento da intensidade de luz, porém não em Cryosophila warscewiczii (Steven et al., 1987). Na palmeira de sub-bosque Geonoma aspidiifolia, o número de perfilhos por touceira tornou-se maior com o aumento da iluminação da coroa (Svenning, 2000), e a produção de perfilhos em Calamus caesius aumentou ao longo de um gradiente de abertura de dossel, com disponibilidade de luz variando de 6-63\% (Bonal, 1997).

Foi sugerido que as palmeiras multicaulinares geralmente fossem restritas a florestas de dossel aberto e a outros hábitats com disponibilidade alta de luz porque os caules adicionais estariam impossibilitados de se desenvolverem devido à sombra em florestas mais fechadas (Kahn \& Castro, 1985), mas esta hipótese ainda precisa de avaliação (Sevenning, 2001). Tomlinson (1990), reforça a hipótese de Kahn (1986) sobre a necessidade crescente de luz para o crescimento de palmeiras caulescentes, discriminado em duas fases. A primeira fase de crescimento corresponde à fase de emissão das primeiras folhas adultas, quando há um progressivo requerimento de luz a intensidades cada vez mais altas. Durante esta fase a maioria das plantas juvenis são acaulescentes, entretanto, algumas espécies apresentam um caule aéreo delgado. A segunda fase corresponde ao desenvolvimento do caule com diâmetro adulto e o requerimento de luz é alto e constante (Figura 1).

Kahn \& Granville (1992) sugeriram que as palmeiras de bosque geralmente apresentam a tendência de serem muito comuns em florestas de várzea, onde o dossel é 
aberto. Vários estudos mostram que a abertura de dossel tem um efeito positivo na ocorrência de palmeiras de bosque.

Palmeiras de bosque e possivelmente palmeiras em touceira (multicaulinar) tendem a serem dependentes sobre as condições de luz, pelo menos para o seu estabelecimento, considerando que palmeira de sub-bosque e palmeira de dossel têm respostas muito diversas à luz. O tamanho médio de abertura de dossel proveniente da queda das árvores favorece o crescimento de Cryosophila guagara na emissão do tronco, entretanto não para estabelecimento de plântulas (Richards \& Williamson, 1975). De acordo com esta interpretação, plântulas e palmeiras jovens de Cryosophila warscewiczii na Costa Rica ocorrem preferencialmente em abertura maiores. Assim, toda a evidência aponta para intensidades de luz relativamente alta para estabelecimento de palmeiras de bosque, embora elas possam persistir como adultos, pelo menos durante algum tempo, em microsítios bastante sombreados.

As palmeiras de sub-bosque são vulneráveis a solarização quando expostas à luz intensa, mas também estão impossibilitadas de manter populações eco-sustentáveis em microsítios fortemente sombreados. Assim pode ser esperado que palmeiras de subbosque evitem grandes aberturas como também microsítios fortemente sombreados. Ainda que a maioria das palmeiras de sub-bosque seja provavelmente afetada negativamente pelo dossel muito aberto, a abertura moderada ou pequena geralmente favorece o desenvolvimento e o estabelecimento das mesmas, mas provavelmente só afete a distribuição de uma minoria de espécies mais responsivas à luz, excluindo as condições de dossel mais permanentemente abertas, como margens ou cumes expostos ao vento. Assim, Kahn e Granville (1992) sugeriram que as altas densidades de Hyospathe elegans and Bactris gastoniana seriam devido à freqüência de queda de árvores na Guiana Francesa.

As diferenças de nicho de luz podem ser o resultado da adaptação das espécies, que diferem constantemente nas exigências por luz ao longo do ciclo de vida, ou em uma parte do ciclo. Um caso especial é quando a espécie muda o grau tolerância à sombra relativa durante o ciclo de vida. As duas palmeiras de dossel mais comuns na floresta Amazônica exibiram tal mudança (Svenning, 1999, 2000b). Palmeiras em 
estádio juvenil Oenocarpus bataua ocorrem independente da disponibilidade de luz, enquanto que Iriartea deltoidea prefere elevadas intensidades de luz (Svenning, 2000b). Com o crescimento em tamanho, O. bataua torna-se restringido a micosítios abertos, resultando em preadultos e adultos baixos, restritas em grande parte a crescerem sob maiores clareiras (Svenning, 1999, 2000b). Iriartea deltoidea jovens também são altamente associados com a abertura de dossel, mas a maioria, com 10-20 m de altura, são achadas sob dossel fechado (Svenning, 1999b). A espécie de sub-bosque Prestoea schultzeana também diminui em tolerância à sombra com tamanho crescente (Svenning, 2000b), enquanto que estas espécies de bosque, Astrocaryum murumuru var. urostachys, A. urostachys e Phytelephas temuicaulis, requerem mais luz quando jovens (Svenning, 2000a). Assim mudanças na tolerância de sombra podem ser bem comuns.

Embora as alterações ontogênicas de tolerância à sombra dificultem categorizarse uma determinada espécie como sombra tolerante ou sombra intolerante, algumas generalizações podem ser feitas, se a tolerância à sombra é julgada pela abertura mínima do dossel necessária para o crescimento e a máxima tolerada para estabelecer a fase adulta. Usando esta definição, as palmeiras de dossel do neotrópico variam de relativamente tolerante à sombra, por exemplo, Iriartea deltoidea, àquelas que requererem altas intensidades de luz, por exemplo, Attalea butyracea, Oenacarpus bataua, Socratea exorrhiza. Notavelmente, Attalea butyracea jovens não apresentaram desidratação e fotoinibição sob $70 \%$ de luz solar, sendo estas condições permanentemente estressantes para Socratea exorrhiza jovens (Araus \& o Hogan, 1994). Até mesmo o requerimento de abertura do dossel pode diferir em exigências de luz. As palmeiras de sub-bosque mostram alcances semelhantes em tolerância de sombra, considerando que as palmeiras de bosque e possivelmente também as palmeiras trepadeiras podem ser mais ecologicamente restritas. Segundo Svenning (2000b) Entre as palmeiras de sub-bosque uma espécie como Prestoea schultzeana precisa de aberturas de dossel significantes, enquanto que uma espécie como Geononza macrostachys var. macrostachys é danificada com aumento da intensidade de luz e até mesmo de uma pequena abertura causada por queda de árvore. A última espécie não pode crescer sob baixa irradiância, e estes microhabitats extremamente sombreados são abertos à espécie 
de porte menor, mais tolerante à sombra (Chazdon, 1985, 1986a, 1986b), como Geonoma stricta var. stricta. Baseado no estudo de arquitetura e ecofisiologia de três palmeiras de sub-bosque, Chazdon (1986b) concluiu que Geonoma cuneata com $1 \mathrm{~m}$ de altura pode reproduzir sob sombra mais intensa que Asterogyne martiana com 1,5 a $2 \mathrm{~m}$ de altura e a Geonoma congesta com 3 a $5 \mathrm{~m}$ de altura. Assim, as palmeiras mostram respostas claras e muito diversas em relação a tolerância à sombra; variando com a ontogênese. $\mathrm{O}$ nicho diferenciado ao longo do gradiente luz é provavelmente um fator local importante na coexistência de palmeiras em florestas tropicais.

Em suma, as investigações quantitativas mostram que as palmeiras de dossel dependem da abertura de clareiras em diferentes proporções e que a tolerância à sombra às vezes muda com a ontogênese. Deste modo, a importância da luz para as palmeiras de dossel é claramente muito menos simples que a proposta original de Kahn (1986). Algumas espécies provavelmente necessitam de grandes aberturas, porém outras necessitam de somente de um mínimo de abertura ou são capazes de crescer mesmo em dossel fechado. Tal fato mostra a necessidade de quantificar intensidades de luz ao longo do crescimento das palmeiras em toda sua ontogênese. 


\section{MATERIAL E MÉTODOS}

\subsection{Caracterização do experimento}

O experimento foi realizado no Campo Experimental do Departamento de Produção Vegetal da Escola Superior de Agricultura "Luiz de Queiroz" da Universidade de São Paulo (ESALQ/USP), localizado no município de Piracicaba (SP), nas coordenadas geográficas $22^{\circ} 42^{\prime} 30^{\prime \prime}$ de latitude Sul e 47 $38^{\prime} 00^{\prime \prime}$ de longitude Oeste, na altitude de $531 \mathrm{~m}$. O clima local é mesotérmico Cwa, ou seja subtropical úmido, com verão chuvoso e estiagem no inverno. As temperaturas médias mensais variam de $24,8^{\circ} \mathrm{C}$ no verão a $17,1^{\circ} \mathrm{C}$ no inverno e a média anual igual a $21,4^{\circ} \mathrm{C}$. A precipitação é de $1.278 \mathrm{~mm}$ ao ano, ocorrendo a maior parte, $1000 \mathrm{~mm}$, nos meses de outubro a março, e $278 \mathrm{~mm}$ de abril a setembro (Sentelhas, 1998).

$\mathrm{O}$ experimento se constitui de três áreas próximas com diferentes coberturas vegetais (Figura 2). A primeira área (A1) plantada em 1981, é constituída de fileiras de leucena (Leucaena leucocephala Lam.) espaçadas de $6 \mathrm{~m} \times 3 \mathrm{~m}$; fileiras de cacaueiro (Theobroma cacao L) - híbrido SCA-12 x ICS-6 a 0,5 m da leucena, espaçados 1,5 m entre si; e fileira de cacaueiro e guarantã (Esenbeckia leiocarpa), a 5,5 m da fileira da leucena, estando as árvores de guarantã, espaçadas $4 \mathrm{~m}$ entre si e a 0,5 m do cacaueiro. A segunda área (A2), é composta por seringueiras (Hevea brasiliensis Muell. Arg.) já adultas, plantadas em fevereiro de 1985, no espaçamento de 7,0 m x 3,0 m, em 24 fileiras em nível. A terceira área (A3), adjacente à seringueira (A2), é uma área com histórico de plantio de culturas de ciclo curto, sujeita a adubações e cultivos anuais. Esta última foi subdividida para caracterização química do solo em A3a, área limitada em até $15 \mathrm{~m}$ da borda da seringueira e A3b, área abrangendo a faixa de 15 a $45 \mathrm{~m}$ da borda da seringueira. 
O solo da área experimental foi classificado como NITOSSOLO VERMELHO Eutrófico Típico, "A" moderado, textura argilosa a muito argilosa (análise granulométrica das áreas A1, A2 e A3 - Tabela 1). Na classificação americana é referido como Kandiudalfic Eutrudox. Mapa pedológico detalhado 1:1.000 do Campus "Luiz de Queiroz", USP, 1993 - não publicado). Os atributos químicos, e a granulometria, dos solos das áreas A1, A2 e A3 (Tabela 1 e 2) foram equalizados quanto à fertilidade com base na A3b. Realizou-se a calagem, para elevar V\% a $70 \%$, e a fosfatagem para elevar o teor de fósforo no solo até $25 \mathrm{mg} \mathrm{de} \mathrm{P}_{2} \mathrm{O}_{5} \mathrm{dm}^{-3}$ nas áreas, três meses antes do plantio das mudas de açaizeiro.

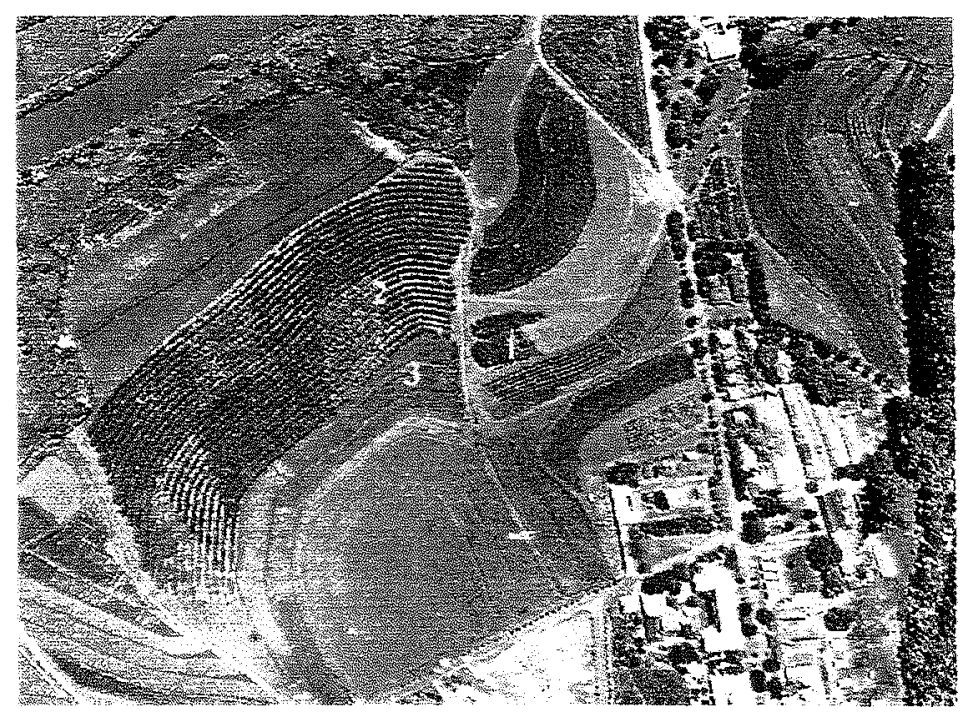

Figura 2 - Foto aérea da área de estudo. (A1) SAF de leucena, cacaueiro e guarantã; (A2) seringueira; (A3) área de plantio anual

As mudas de açaizeiro foram produzidas a partir de sementes coletadas em mata de várzea do Estuário Amazônico nas proximidades de Abaetetuba - PA. O plantio das mudas ocorreu aos 18 meses após a germinação, em novembro de 2001, quando apresentaram duas folhas pinadas e diâmetro basal de 0,0125 m. A cova de plantio, nas dimensões de $0,40 \times 0,40 \times 0,40 \mathrm{~m}$, recebeu $2 \mathrm{~kg}$ de esterco de gado e 0,60 $\mathrm{kg}$ de super fosfato simples. A adubação, durante os dois primeiros anos, foi em cobertura conforme a recomendação de Nogueira et al.(1995). 
Tabela 1. Granulometria dos solos nas áreas A1, A2, e A3a e A3b. Amostra composta de 10 subamostras com três repetições na profundidade de $20 \mathrm{~cm}$

\begin{tabular}{|c|c|c|c|c|}
\hline & Areia & Silte & Argila & Classe \\
\hline & $\mathrm{g} \mathrm{kg}^{-1}$ & $\mathrm{~g} \mathrm{~kg}^{-1}$ & $\mathrm{~g} \mathrm{~kg}^{-1}$ & Textural \\
\hline A1 & 35 & 16 & 49 & argilosa \\
\hline $\mathrm{A} 2$ & 30 & 15 & 55 & argilosa \\
\hline $\mathrm{A} 3 \mathrm{a}$ & 30 & 15 & 55 & argilosa \\
\hline $\mathrm{A} 3 \mathrm{~b}$ & 27 & 13 & 60 & muito argilosa \\
\hline
\end{tabular}

Tabela 2. Atributos químicos dos solos nas áreas $\mathrm{A} 1, \mathrm{~A} 2$, e $\mathrm{A} 3 \mathrm{a}$ e $\mathrm{A} 3 \mathrm{~b}$. Amostra composta de 10 subamostras com três repetições na profundidade de $20 \mathrm{~cm}$

\begin{tabular}{|c|c|c|c|c|c|c|c|c|c|c|c|c|}
\hline \multicolumn{2}{|c|}{$\mathrm{pH}$} & M.O & $\mathrm{P}$ & $\mathrm{K}$ & $\mathrm{Ca}$ & $\mathrm{Mg}$ & $\mathrm{Al}$ & $\begin{array}{c}\mathrm{H}+\mathrm{A} \\
1\end{array}$ & SB & $\mathrm{T}$ & $\mathrm{V}$ & $\mathrm{m}$ \\
\hline & $\mathrm{CaCl}_{2}$ & $\mathrm{~g} \mathrm{~m}^{-3}$ & $\mathrm{mg} \mathrm{dm}_{3}^{-}$ & \multicolumn{7}{|c|}{$\mathrm{mmolc} \mathrm{dm}^{-3}$} & \multicolumn{2}{|c|}{$\%$} \\
\hline $\mathrm{A} 1$ & 5,1 & 28,7 & 9,0 & 7,9 & 31,7 & 13,7 & 0,3 & 32,0 & 53,3 & 85,3 & 64,0 & 0,7 \\
\hline A2 & 4,4 & 24,3 & 9,7 & 4,8 & 15,0 & 5,3 & 3,3 & 50,3 & 25,2 & 75,5 & 41,3 & 11,7 \\
\hline $\mathrm{A} 3 \mathrm{a}$ & 5,3 & 24,7 & 21,3 & 5,5 & 27,3 & 16,3 & 0,5 & 28,0 & 49,1 & 77,1 & 52,3 & 0,7 \\
\hline $\mathrm{A} 3 \mathrm{~b}$ & 5,6 & 23,0 & 26,3 & 4,4 & 36,7 & 18,0 & 0,0 & 24,0 & 59,0 & 83,0 & 71,2 & 0,0 \\
\hline
\end{tabular}

As mudas de açaizeiro foram plantadas no espaçamento $2 \mathrm{~m} \times 2 \mathrm{~m}$, nas áreas $\mathrm{A} 1$, A2 e A3, constituindo os seguintes tratamentos (Figura 3):

1) SAF constituído por leucena, guarantã, cacaueiro e açaizeiro $\left(\mathbf{C A C}_{\mathbf{1}}\right.$ e $\left.\mathbf{C A C}_{2}\right)$ : duas fileiras de açaizeiros, entre as fileiras de leucena, guarantã e cacaueiro;

2) SAF constituído por seringueira e açaizeiro nas entrelinhas $\left(\mathbf{S E R}_{\mathbf{1}} \mathbf{e} \mathbf{S E R _ { 2 }}\right)$ : duas fileiras de açaizeiro entre as fileiras de seringueira;

3) SAF constituído pela transeção de açaizeiro e seringueira: açaizeiro a $\mathbf{1 , 5} \mathbf{m}, \mathbf{5 , 5} \mathbf{m}$, 9,5 m, 15,5 m, 23,5 m e 31,5 $\mathrm{m}$ de distância a partir da borda da seringueira. 

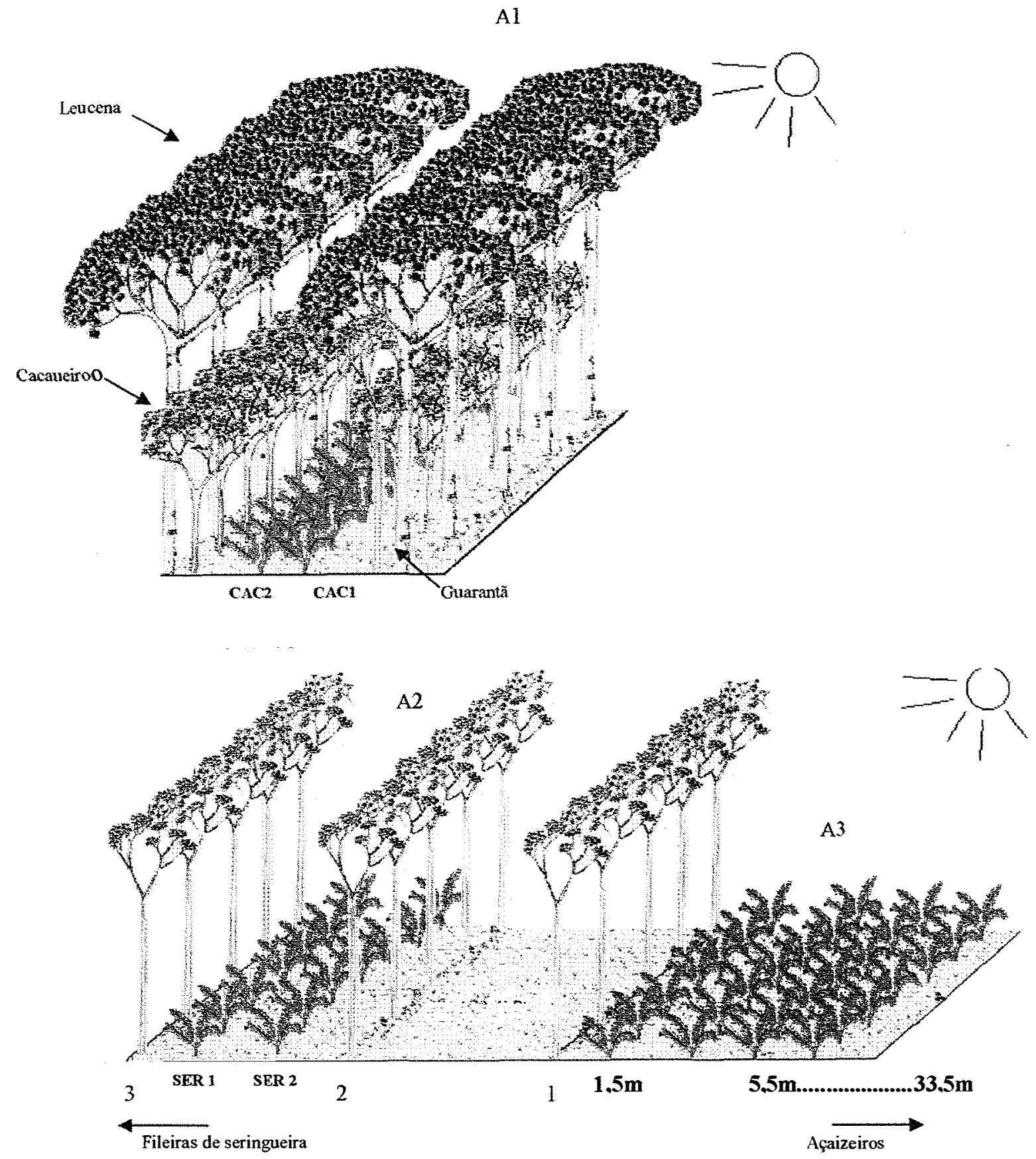

Figura 3 - Blocos esquemáticos dos tratamentos: $\mathrm{CAC}_{1}$ e $\mathrm{CAC}_{2}$; $\mathrm{SER}_{1}$ e $\mathrm{SER}_{2}$; e 1,5 m, $5,5 \mathrm{~m}, 9,5 \mathrm{~m}, 15,5 \mathrm{~m}, 23,5 \mathrm{~m}$ e $31,5 \mathrm{~m}$ 


\subsection{Medidas do ambiente}

Foram medidas a irradiância disponível para o açaizeiro, a temperatura do ar e do solo e a tensão de água no solo no período de maior variação da área foliar da seringueira, isto é, de maio a outubro (2002) e em março (2003).

A irradiância no topo da copa dos açaizeiros foi medida com tubos solarímetros (TSL, Delta-T Device) ligados a uma estação automática de tomada de dados (DL2e, Delta T Devices), programada para obter dados a cada 5 segundos e armazená-los a cada 30 minutos, nos meses mencionados anteriormente. Nos demais meses, a irradiância foi estimada pela equação de Monsi \& Saeki (1953) com as medidas do índice de área foliar (IAF) do dossel das árvores obtidas com o LAI 2000 ou através da interpolação das medidas de irradiância acumuladas entre os meses.

A tensão de água no solo foi medida na profundidade de $0,2 \mathrm{~m}$ e $0,40 \mathrm{~m}$ à $0,20 \mathrm{~m}$ do açaizeiro. Utilizou-se para essas medidas os tensiômetros do tipo SWT3 (Delta-T Devices), nos tratamentos $\mathrm{SER}_{2}, 1,5 \mathrm{~m}$ e 33,5m, em junho de 2002; e os tensiômetros de mercúrio, em fevereiro de 2003, nos tratamentos $\mathrm{CAC}_{\mathrm{le} 2}, \mathrm{SER}_{1 \mathrm{e} 2}, 1,5 \mathrm{~m}$, $5,5 \mathrm{~m}, 15,5 \mathrm{~m}, 12,5 \mathrm{~m}$ e $33,5 \mathrm{~m}$.

As medidas de temperatura do solo e do ar foram tomadas às $7 \mathrm{~h}, 13 \mathrm{~h}$ e $17 \mathrm{~h}$, nos meses de junho, julho, agosto, setembro de 2002 e março de 2003, nos tratamentos $\mathrm{CAC}_{1 \mathrm{e} 2}, \mathrm{SER}_{1 \mathrm{e} 2}, 1,5 \mathrm{~m}$ e $33,5 \mathrm{~m}$. Para essas medidas foram utilizados termômetro de solo na profundidade de $5 \mathrm{~cm}$ e psicrômetro de aspiração forçada tipo Assmann posicionado a $1 \mathrm{~m}$ de altura.

As medidas de irradiância, temperatura do solo e do ar foram utilizadas na estimativa da evapotranspiração potencial pelo método de Penman-Monteith, padrão FAO, conforme descrito por Sentelhas (1998).

\subsection{Parâmetros do açaizeiro}

Foram amostradas 12 plantas consecutivas de cada tratamento e tomadas as medidas da altura e do diâmetro da haste principal e da área foliar total, incluindo a área foliar dos perfilhos, em quatro épocas: novembro de 2001, maio e novembro de 2002 e maio de 2003. Os intervalos entre as épocas constituíram os períodos de crescimento: 
P1, P2 e P3. As medidas de altura e diâmetro da haste principal foram efetuadas segundo a recomendação de Clemente \& Bovi (2000). A área foliar foi medida com o auxílio de analisador portátil de área foliar da LI-COR - LAI 3200A.

Coletaram-se três plantas de cada sistema (30 plantas), em julho de 2003, para avaliação da massa seca da parte aérea, incluindo os perfilhos. Nessa época a calibração da equação 1, relacionando altura e diâmetro da haste principal e área foliar com massa seca da parte aérea por planta, apresentou $p<0,0001 \mathrm{e} \mathrm{r}^{2}=0,91$.

$$
\mathrm{M}=0,098+360,08\left[0,33(\mathrm{D} / 2)^{2} \mathrm{HAF}\right]
$$

em que $\mathrm{M}\left(\mathrm{g} \cdot \mathrm{pl}^{-1}\right)$ refere-se à massa seca da parte aérea da planta; $\mathrm{D}(\mathrm{m})$ ao diâmetro da haste principal a $0,1 \mathrm{~m}$ do solo; $\mathrm{H}(\mathrm{m})$ à altura da haste principal medida na junção da última folha aberta e a flecha; $\mathrm{AF}\left(\mathrm{m}^{2}\right)$ à área foliar total da planta ou touceira.

As taxas de crescimento absoluto ( $\mathrm{TCA} \mathrm{g} \mathrm{pl}^{-1}$ ), crescimento relativo (TCR $\mathrm{g} \mathrm{g}^{-1}$ ),

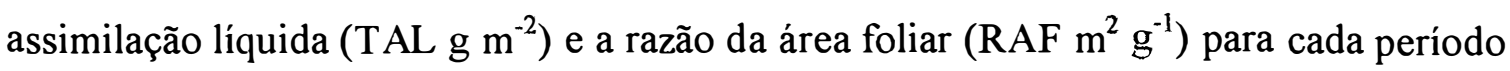
de crescimento, foram calculadas segundo modelo clássico de análise citado por Causton \& Venus (1981):

$$
\begin{aligned}
& \mathrm{TCA}=\left(\mathrm{Mn}-\mathrm{Mn}_{-1}\right) /\left(\mathrm{En}^{-E_{-1}}\right) ; \\
& \mathrm{TCR}=\left(\mathrm{LnMn}_{\mathrm{LnMn}} \mathrm{Ln}_{-1}\right) /\left(\mathrm{En}-\mathrm{En}_{1}\right) ; \\
& \mathrm{TAL}=\left[\left(\mathrm{Mn}_{-} \mathrm{Mn}_{-1}\right) /\left(\mathrm{AFn}^{-} \mathrm{AFn}_{-1}\right)\right]^{*}\left[\left(\operatorname{LnAFn}_{-} \mathrm{LnAfn}_{-1}\right) /\left(\text { En-En }_{-1}\right)\right] ; \\
& \mathrm{RAF}=\left(\mathrm{AFn}+\mathrm{AFn}_{-1}\right) /\left(\mathrm{Mn}+\mathrm{Mn}_{-1}\right) \text {; }
\end{aligned}
$$

onde $\mathrm{M}\left(\mathrm{g} \cdot \mathrm{pl}^{-1}\right)$ refere-se à massa seca da parte aérea estimada através da equação $1, \mathrm{AF}\left(\mathrm{m}^{2}\right)$ à área foliar total (planta mãe e perfilhos), $\mathrm{E}$ às épocas de medidas, e $\mathrm{n}$ refere-se a épocas: 0 - novembro de 2001, 1 - maio de 2002; 2 - novembro de 2002; e 3 maio de 2003.

A eficiência do uso da radiação foi estimada através da relação linear entre o acúmulo da massa seca e a irradiância disponível para as plantas, nos períodos de crescimento e nos tratamentos. O método é uma modificação daquele proposto por Sinclair \& Muchow (1999), que utiliza a irradiância interceptada. Assim, a eficiência do uso da radiação será referida nesse trabalho como RUEd. 
O efeito da irradiância no acúmulo de massa seca da parte aérea, na área foliar total, na altura e no diâmetro da haste principal (planta mãe), dos açaizeiros nos sistemas foi avaliado através da regressão para cada período de crescimento (P1, P2 e P3). As taxas de crescimento medidas nos períodos foram avaliadas com a análise multivariada de medidas repetitivas no tempo seguida do teste de Tukey a $5 \%$ de probabilidade. Convém lembrar que esse tipo de abordagem envolve análises de variância uni e multivariada, estabelecendo-se compromisso entre ambas, de modo a validar os testes $F$ para o efeito tempo e para a interação envolvendo tal efeito. O programa SAS foi usado para as referidas análises com os procedimentos RSREG e GLM. 


\section{RESULTADOS}

\subsection{Medidas do ambiente}

No P1 (novembro/01 a maio/02) e no P3 (novembro/02 a maio/03), típicos do verão chuvoso, a temperatura média das mínimas e das máximas foi de 18 e $29^{\circ} \mathrm{C}$. Nesses dois períodos a precipitação pluviométrica e a radiação global apresentaram valores semestrais acumulados de 1163 e $941 \mathrm{~mm}$ e de 3.686 e 3.166 a $\mathrm{MJ} \mathrm{m}^{-2}$, respectivamente.

No P2 (maio/02 a novembro/02) a temperatura média das mínimas e das máximas foi de 14 e $28^{\circ} \mathrm{C}$, sendo registrado em julho a temperatura mínima absoluta do período de $10^{\circ} \mathrm{C}$. Nesse período a precipitação pluviométrica e a radiação global foram de $184 \mathrm{~mm}$ e $2.601 \mathrm{MJ} \mathrm{m}^{-2}$, respectivamente. A baixa precipitação nesse período confere uma deficiência hídrica típica que pode chegar a $25 \mathrm{~mm}$ conforme o balanço hídrico climatológico normal de 1917 a 1997 (Sentelhas, 1998). O fornecimento de água via irrigação, no P2, aumentou a precipitação para $530 \mathrm{~mm}$.

As variações mensais são apresentadas na Figura 4. A precipitação no Pl foi mais uniforme nos primeiros meses após o plantio favorecendo o pegamento das mudas.

\subsubsection{Irradiância}

A irradiância disponível para o açaizeiro variou entre os diferentes sistemas e posições. A menor irradiância foi observada no sistema sob cacaueiro, guarantã e leucena (CAC). A partir do sistema sob seringueira (SER) para as distâncias crescentes da sua borda, a irradiância aumentou, até os maiores valores na posição de $33,5 \mathrm{~m}$ (Figura 5). Por outro lado, os dois tipos de cobertura vegetal, o sistema sob cacaueiro, guarantã e leucena (CAC) e o sistema sob seringueira (SER), apresentaram perda de folhas no P2 (maio a novembro de 2002) aumentando a disponibilidade relativa de 
irradiância. Esse aumento nos sistemas sob dossel foi tão relevante, que a irradiância disponível absoluta foi maior nesse período do que nos dois períodos de verão. Ademais, o aumento foi mais importante sob as seringueiras. Isso ocorreu devido à sua desfolha completa, pelo caráter decíduo da espécie, e à desfolha parcial das espécies semidescíduas da cobertura do $\mathrm{CAC}$, cacaueiro, guarantã e leucena. $\mathrm{O}$ aumento na disponibilidade da irradiância para as palmeiras sob dossel das árvores com a desfolha foi de $4,5 \%\left(\mathrm{CAC}_{2}\right)$ e $6,6 \%\left(\mathrm{CAC}_{1}\right)$ para $7,2 \%\left(\mathrm{CAC}_{2}\right)$ e $10,8 \%$; e de $18,3 \%\left(\mathrm{SER}_{1}\right)$ e $21,4 \%\left(\mathrm{SER}_{2}\right)$ para $34,7 \%\left(\mathrm{SER}_{1}\right)$ a $39,8 \%\left(\mathrm{SER}_{2}\right)$.

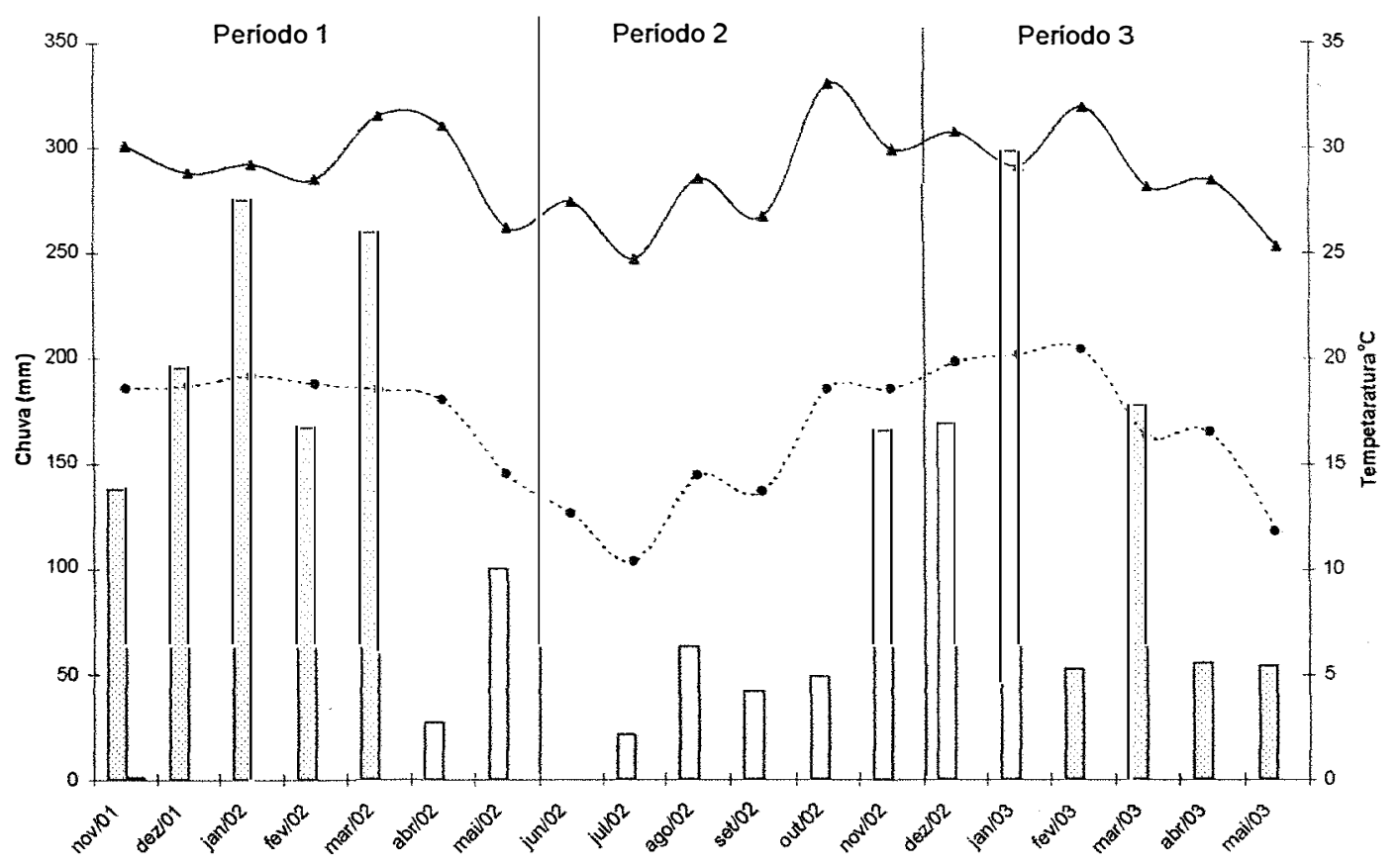

Figura 4 - Valores mensais de temperatura mínima média (linha descontínua) e máxima média (linha contínua), e chuva (barras), de novembro de 2000 a maio de 2003, em Piracicaba-SP. Dados do posto meteorológico da ESALQ. Coordenadas geográficas: $22^{\circ} 42^{\prime} 30^{\prime \prime}$ de latitude Sul; $47^{\circ} 38^{\prime} 00^{\prime \prime}$ de longitude Oeste; e $580 \mathrm{~m}$ de altitude

Nas distância crescentes das fileiras de açaizeiro, a irradiância relativa foi de $27,7 \%, 51,7 \%, 62,1 \%, 78,3 \%, 85,3 \%, 88,3 \%$ a $1,5 \mathrm{~m}, 5,5 \mathrm{~m}, 9,5 \mathrm{~m}, 15,5 \mathrm{~m}, 23,5 \mathrm{~m}$ e $33,5 \mathrm{~m}$, com variações pouco expressivas no P2. Nesse período o aumentou da 
irradiância relativa, em torno de $3 \%$, não resultou em maior disponibilidade absoluta para o açaizeiro (Figura 5).

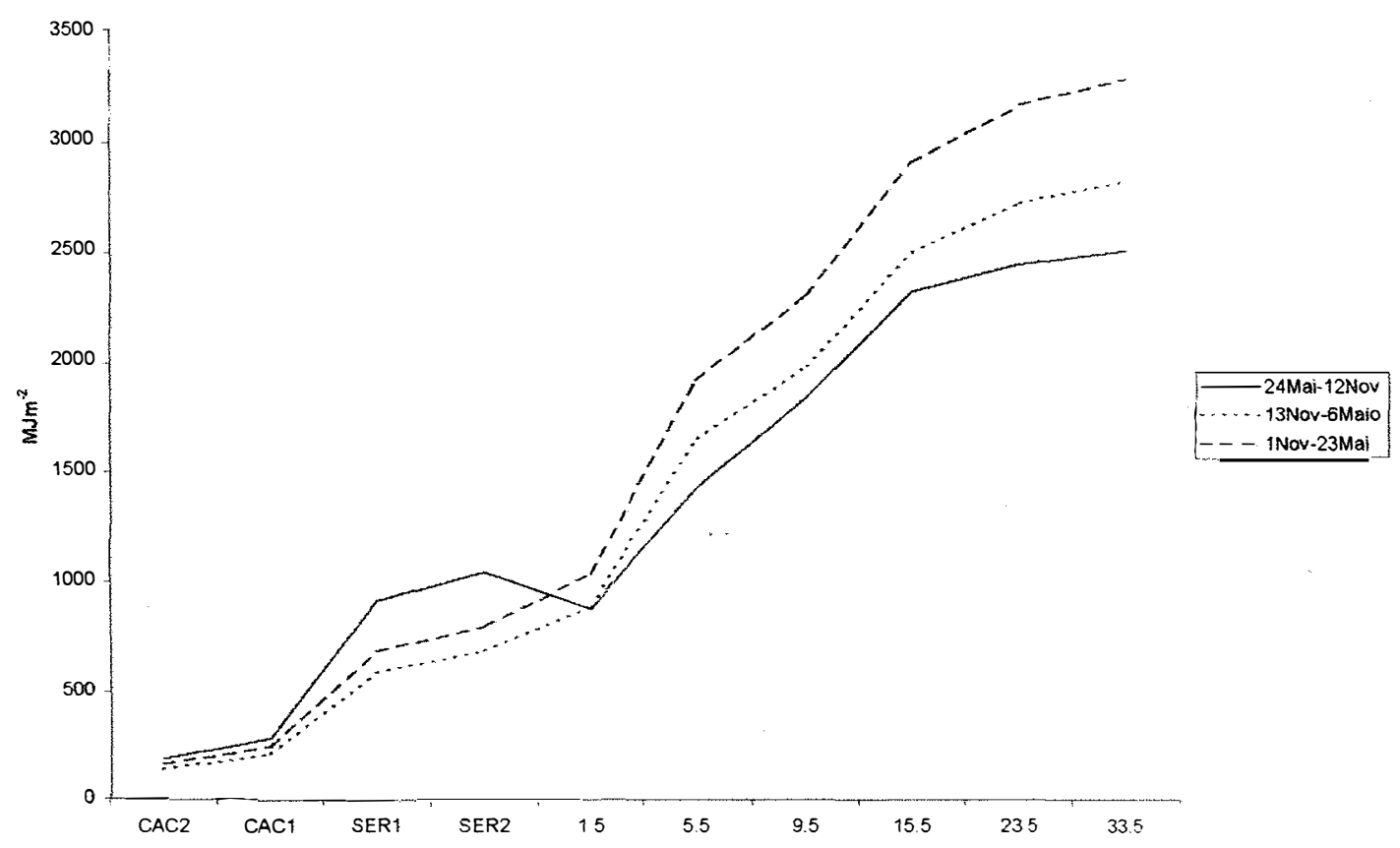

Figura 5 - Irradiância disponível para o açaizeiro nos sistemas agroflorestais nos

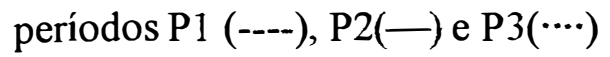

Independente do sistema, a maior parte da radiação foi interceptada durante o período matutino (Figura 6). As medidas horárias de irradiância, num dia claro e com presença de nuvens, mostram o deslocamento da sombra com o ângulo de inclinação solar. Após as duas primeiras horas da manhã as fileiras de açaizeiro vão sendo sombreadas gradualmente ao longo do dia até a $15,5 \mathrm{~m}$ da seringueira. $\mathrm{O}$ deslocamento transversal do sol às fileiras da seringueira permite a obtenção de um pico de irradiância no período matutino, e outro no período vespertino para as plantas à $1,5 \mathrm{~m}$ da seringueira. Nos sistemas sob dossel das árvores, os feixes de radiação direta ocorrem em diversos horários, evidenciando a descontinuidade do dossel superior das árvores e maior radiação para os açaizais. A fileira de açaizeiro mais próxima ao exterior das fileiras de seringueira $\left(\mathrm{SER}_{2}\right)$ foi mais favorecida que a mais no interior $\left(\mathrm{SER}_{1}\right)$ em relação à disponibilidade de irradiância. Dentro do CAC, a descontinuidade do dossel superior 
requer maiores cuidados na amostragem da disponibilidade da radiação devido à variabilidade espacial.

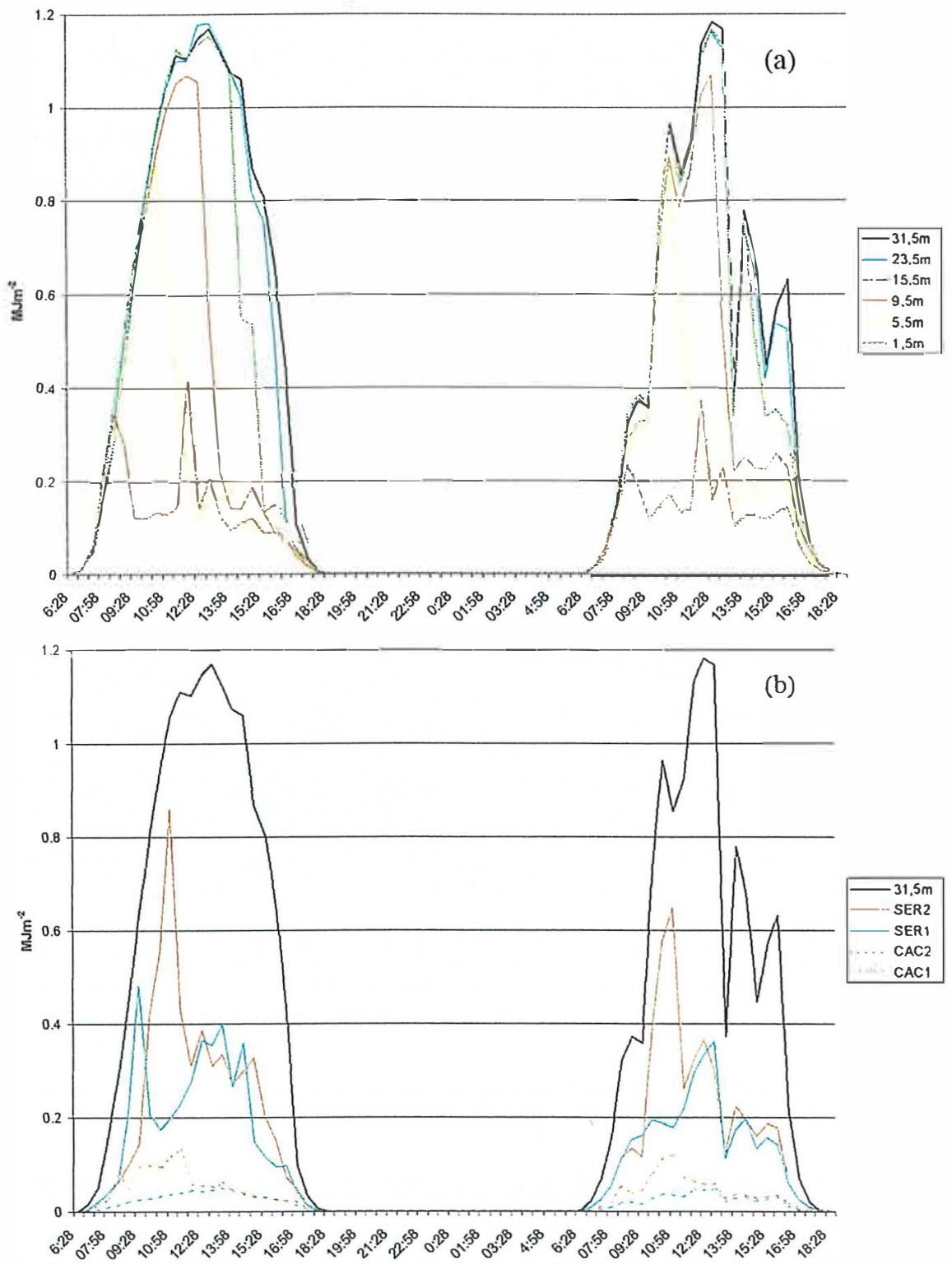

Figura 6 - Irradiância disponível para o açaizeiro ao longo dos dias 17 e 18 de maio de 2002. (a) nas distâncias das fileiras de açaizeiro em relação à fileira de seringueira na transeção; e (b) sob dossel de seringueira $\left(\mathrm{SER}_{1}\right.$ e $\left.\mathrm{SER}_{2}\right)$ e de leucena guarantã e cacaueiro $\left(\mathrm{CAC}_{1}\right.$ e $\left.\mathrm{CAC}_{2}\right)$ 


\subsubsection{Temperatura do ar e do solo e déficit de pressão de vapor do ar}

A presença das árvores alterou a temperatura do ar e do solo e o défícit de pressão de vapor d'água para as plantas sob a sua copa (Tabela 3). A variação mensal da temperatura entre os sistemas foi influenciada pelo tipo de copa em função da taxa de irradiância transmitida.

Tabela 3. Temperaturas média, máxima, mínimas do ar e do solo e déficit de pressão de vapor (DPV- hPa), nos meses de junho, julho, agosto, setembro de 2002 e março de 2003 para os sistemas CAC, SER, 1,5m e 33,5m

\begin{tabular}{|c|c|c|c|c|c|}
\hline & \multicolumn{2}{|c|}{ Temperatura do ar $\left({ }^{\circ} \mathrm{C}\right)$} & \multicolumn{2}{|c|}{ Temperatura do solo $\left({ }^{\circ} \mathrm{C}\right)$} & \multirow{2}{*}{$\begin{array}{c}\mathrm{DPV}(\mathrm{hPa}) \\
\text { Média }\end{array}$} \\
\hline & Máxima & Minima & Máxima & Mínima & \\
\hline \multicolumn{6}{|c|}{ CAC } \\
\hline jun/02 & 24,14 & 14,92 & 16,95 & 15,35 & 2,58 \\
\hline jul/02 & 22,87 & 11,52 & 15,98 & 13,93 & 1,90 \\
\hline ago/02 & 25,35 & 16,10 & 18,00 & 16,15 & 2,14 \\
\hline set/02 & 21,20 & 8,80 & 15,00 & 14,40 & 2,35 \\
\hline $\mathrm{mar} / 03$ & 25,83 & 20,92 & 23,66 & 19,89 & 2,77 \\
\hline \multicolumn{6}{|c|}{ SER } \\
\hline jun/02 & 26,42 & 15,24 & 19,10 & 15,75 & 3,48 \\
\hline $\mathrm{jul} / 02$ & 24,32 & 10,72 & 17,42 & 13,62 & 2,33 \\
\hline ago/02 & 25,90 & 15,40 & 19,75 & 17,35 & 2,44 \\
\hline set/02 & 22,33 & 8,47 & 16,27 & 14,07 & 2,75 \\
\hline $\operatorname{mar} / 03$ & 26,75 & 20,87 & 23,10 & 19,91 & 3,50 \\
\hline \multicolumn{6}{|c|}{$1,5 \mathrm{~m}$} \\
\hline jun/02 & 25,44 & 15,24 & 18,90 & 14,98 & 3,51 \\
\hline $\mathrm{jul} / 02$ & 24,00 & 10,82 & 18,80 & 11,97 & 2,70 \\
\hline ago/02 & 26,10 & 15,85 & 19,10 & 16,35 & 3,58 \\
\hline set/02 & 22,13 & 8,67 & 15,53 & 11,80 & 2,66 \\
\hline $\mathrm{mar} / 03$ & 27,04 & 21,08 & 23,10 & 19,91 & 3,68 \\
\hline \multicolumn{6}{|c|}{$33,5 m$} \\
\hline jun/02 & 26,12 & 14,66 & 18,00 & 15,55 & 3,79 \\
\hline $\mathrm{jul} / 02$ & 24,87 & 10,67 & 20,60 & 11,97 & 3,93 \\
\hline ago/02 & 27,25 & 15,35 & 23,40 & 15,85 & 4,59 \\
\hline set/02 & 22,67 & 8,27 & 21,73 & 10,00 & 3,00 \\
\hline $\mathrm{mar} / 03$ & 28,79 & 21,11 & 30,55 & 20,43 & 5,53 \\
\hline
\end{tabular}


No sistema $\mathrm{CAC}$ as temperaturas médias foram menores comparadas com os outros sistemas durante todos os meses avaliados. As temperaturas máximas nesse sistema chegaram a ser $3^{\circ} \mathrm{C}$ menor, conforme observado no mês de março.

A temperatura média do ar nas fileiras de açaizeiro sob e adjacentes a seringueira foram equivalentes nos meses de junho a setembro, período de maior irradiância para o açaizeiro no sistema SER. Ao passo que em março 2003, no período de menor irradiância para as plantas sob dossel, a temperatura média chegou a ser $1^{\circ} \mathrm{C}$ menor sob a seringueira e a $1,5 \mathrm{~m}$ comparada às fileiras a $33,5 \mathrm{~m}$ da seringueira. Observa-se que as diferenças são devido às maiores variações nas temperaturas máximas que chegam a $3^{\circ} \mathrm{C}$ a mais para as plantas a $33,5 \mathrm{~m}$. Tal comportamento também pode ser empregado no entendimento da variação da temperatura do solo. No CAC, o déficit de pressão de vapor foi menor para as plantas sob dossel chegando a $50 \%$ no mês de março.

\subsubsection{Potencial mátrico de água no solo $\left(\psi_{\mathrm{m}}\right)$}

Os valores de $\psi_{\mathrm{m}}$ variaram de 540 a $808 \mathrm{hPa}$ e de 84 a $421 \mathrm{hPa}$ na profundidade de $20 \mathrm{~cm}$, e de 487 a $616 \mathrm{hPa}$ e de 26 a $614 \mathrm{hPa}$ na profundidade de $40 \mathrm{~cm}$ nos meses de maio a julho/02 e em março/03 (Figura 7).

As posições sob sombra das árvores apresentaram valores de $\psi_{\mathrm{m}}$ maiores na profundidade de $40 \mathrm{~cm}$ do que na profundidade de $20 \mathrm{~cm}$; invertendo nas posições de maior irradiância. Entretanto, nos meses de desfolhamento da seringueira, não houve diferença no comportamento do $\psi_{\mathrm{m}}$ entre as profundidades nas diferentes posições, mantendo-se a profundidade $20 \mathrm{~cm}$ maiores potenciais que na profundidade $40 \mathrm{~cm}$. Neste período pouca variação ocorreu entre os $\psi_{\mathrm{m}}$ nos ambientes agroflorestais.

\subsubsection{Evapotranspiração de referência}

A evapotranspiração de referência (ETo) diária variou com a presença das árvores nos meses de junho a setembro/02 e março/03 (Figura 8). O sistema CAC manteve ETo estável em torno de $0,4 \mathrm{~mm} \mathrm{dia}^{-1}$. Em junho e julho ocorreu a maior demanda para os sistemas sob dossel da seringueira (SER), $2 \mathrm{~mm} \mathrm{dia}{ }^{-1}$, aproximadamente o dobro do observado nos meses de agosto, setembro e março. Os 
valores de ETo para plantas à 1,5m apresentaram-se ligeiramente mais elevados nesses três meses. As maiores ETo ocorreram nas fileiras distanciadas a 33,5 m, e variaram de 3,1 a $6,9 \mathrm{~mm} \mathrm{dia}^{-1}$.
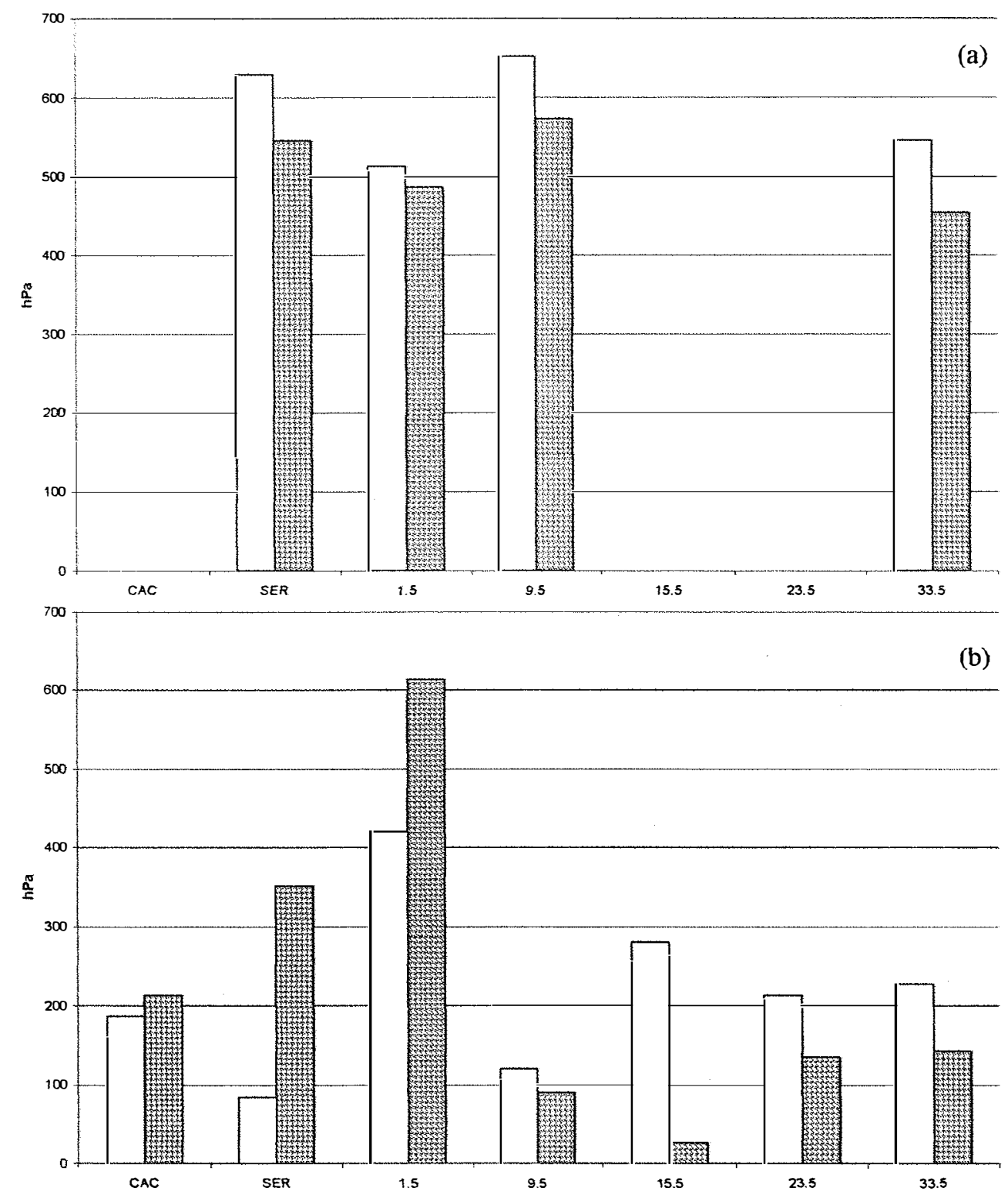

Figura 7 - Potencial mátrico de água no solo em duas profundidades, 0-20 (col. vazia) e 20-40 (col. cheia), nos sistemas CAC, SER, 1,5m e 33,5m, nos meses de julho de 2002 (a) e março de 2003 (b) 


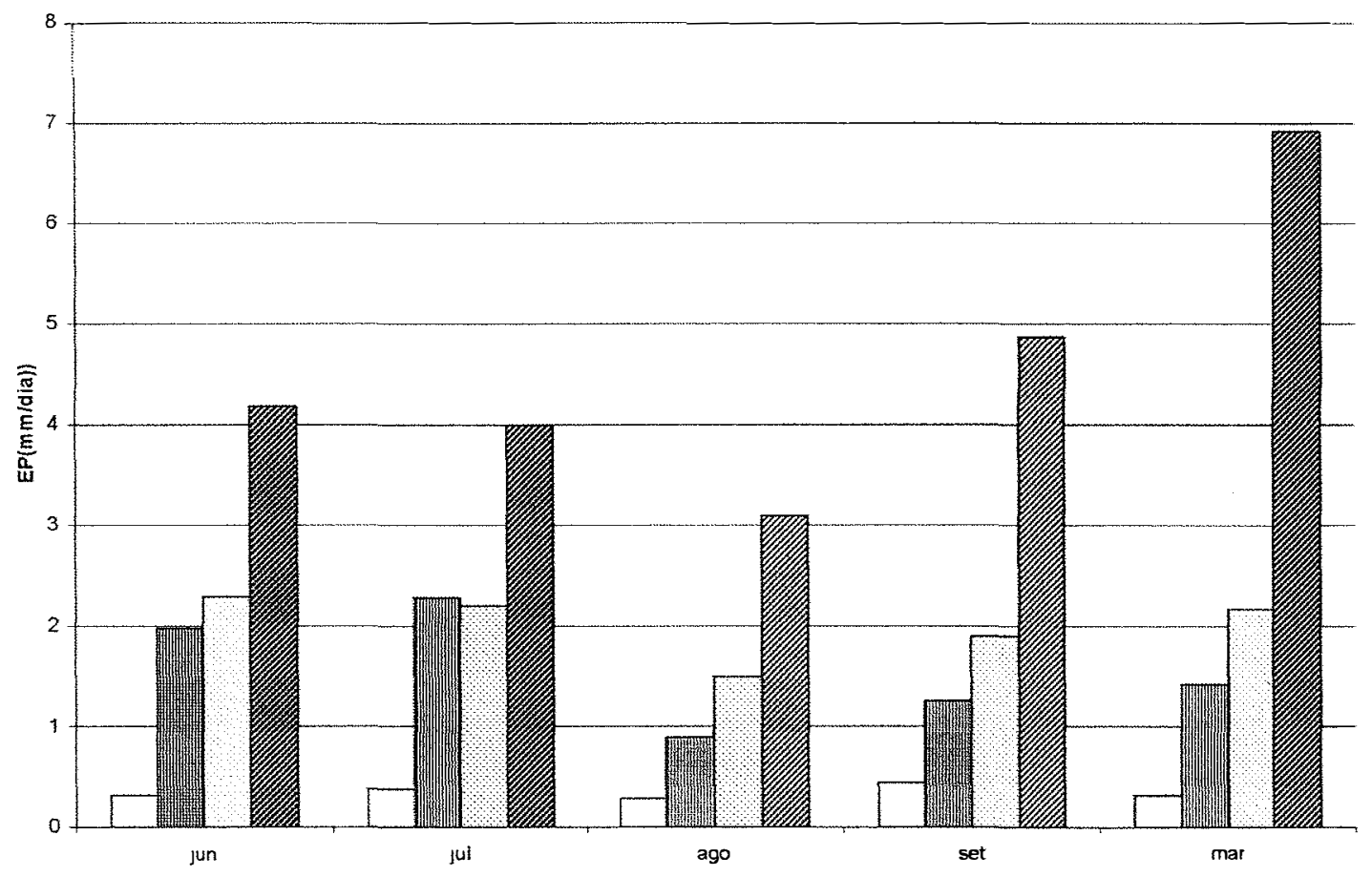

Figure 8 - Evapotranspiração de referência diária nos meses de junho a setembro de 2002 e no mês de março de 2003, nos sistemas: CAC(sem barra), SER(barra vertical), $1,5 \mathrm{~m}$ (pontos) e $33,5 \mathrm{~m}$ (barra inclinada) $\cdots$

A presença das árvores alterou as condições de microclima para as plantas. A tendência da ETo, sem o componente arbóreo, seria de aumento da demanda evapotranspiratória de junho a março, devido ao aumento da irradiância e da temperatura do ar e do solo. Entretanto, a maior densidade de cobertura vegetal no sistema CAC manteve a ETo quase constante ao longo dos meses; e o comportamento caducifólio da espécie arbórea do sistema SER, inverteu a tendência da Eto apresentada na transeção.

Nos meses de junho e julho ou mesmo em março, a presença das árvores reduziu a ETo para mais de $50 \%$ no sistema SER e mais de $90 \%$ no sistema CAC. Considerando uma média diária de chuva mais a irrigação fornecida no mês de julho, o fornecimento de água para os sistemas ficou em torno de $1,5 \mathrm{~mm}$, isto é, $30 \%$ da demanda ETo encontrada na distância $33,5 \mathrm{~m}$. 


\subsection{Análise de crescimento}

\subsubsection{Massa seca da parte aérea, área foliar, altura e diâmetro das plantas}

O efeito da irradiância acumulada na produção da massa seca da parte aérea, na área foliar, no diâmetro da haste principal e na altura das plantas foi descrito através das funções matemáticas, lineares ou quadráticas. A relação entre a irradiância e os parâmetros das plantas aumentaram com o crescimento, conforme verificado nos valores crescentes dos coeficientes angulares e de determinação das equações na Tabela 4. A altura das plantas foi exceção pois apresentou pouca alteração no ângulo de inclinação da reta com a idade.

Tabela 4. Irradiância acumulada e produção de massa seca da parte aérea (M-g), área foliar da haste principal e do perfilho $\left(\mathrm{AF}-\mathrm{m}^{2}\right)$, diâmetro da haste principal (Dm) e altura da planta (H-m), área foliar do perfilho (AFP- $\left.\mathrm{m}^{2}\right)$ e área foliar do perfilho em relação ao da haste principal (AFPM- ${ }^{2}$ ) em três períodos de crescimento P1, P2 e P3

\begin{tabular}{|c|c|c|c|c|c|c|c|}
\hline Variável & Periodo & Equações de regressão & $R^{2}$ & & $C V(\%)$ & $y_{\max }$ & $x$ para $y_{\max }$ \\
\hline \multirow[t]{3}{*}{$M$} & $\mathrm{Pl}$ & $y=130,7+0,00925 x$ & 0,1366 & $* *$ & 18,17 & & \\
\hline & $\mathrm{P} 2$ & $y=99,99+0,12361 x-0,00001680 x^{2}$ & 0.2970 & ** & 36,99 & 327,32 & 3678 \\
\hline & P3 & $y=3,63+0,227684 x-0,00001644 x^{2}$ & 0,4638 & ** & 50,79 & 792,05 & 6925 \\
\hline \multirow[t]{3}{*}{ AFT } & $\mathrm{P} 1$ & $y=0,33265+0,00007458 x$ & 0,2859 & $* *$ & 29,92 & & \\
\hline & $\mathrm{P} 2$ & $y=0,40836+0,000344 x-0,00000004108 x^{2}$ & 0,3742 & ** & 30,18 & 1,12 & 4185 \\
\hline & P3 & $y=0,2887+0,000606 x-0,00000003581 x^{2}$ & 0,6572 & $* *$ & 32,42 & 2,85 & 8455 \\
\hline \multirow[t]{3}{*}{$D$} & PI & $y=0,022308+0,000007044 x-0,0000000014 x^{2}$ & 0,3092 & ** & 14,28 & 0,0309 & 2447 \\
\hline & $\mathrm{P} 2$ & $y=0,019835+0,000011199 x-0,000000001389 x^{2}$ & 0,4998 & ** & 18,22 & 0,0424 & 4028 \\
\hline & P3 & $y=0,01928+0,000012043 x-0,0000000009733 x^{2}$ & 0,6866 & ** & 16,90 & 0,0566 & 6205 \\
\hline \multirow[t]{3}{*}{$\mathrm{H}$} & $\mathrm{P} 1$ & & 0,0069 & ns & 23,39 & & \\
\hline & $\mathrm{P} 2$ & $y=0,2431+0,000126 x-0,0000000193341 x^{2}$ & 0,2489 & $* *$ & 25,74 & 0,4498 & 3269 \\
\hline & P3 & $y=0,2334+0,000125 x-0,00000001105969 x^{2}$ & 0,4700 & $* *$ & 22,11 & 0,5874 & 5660 \\
\hline \multirow[t]{2}{*}{ AFP } & P2 & $Y=0,00002615 x$ & 0,2476 & ** & 165,53 & & \\
\hline & P3 & $Y=0,000118 x$ & 0,4081 & ** & 104,57 & & \\
\hline \multirow[t]{2}{*}{ AFPM } & P2 & $Y=0,000023 x$ & 0,2787 & ** & 147,57 & & \\
\hline & P3 & $Y=0,000041 x$ & 0,5110 & ** & 73,13 & & \\
\hline
\end{tabular}

**: significatico ao nivel del\% de probabilidade; ns: não significatico a $1 \%$ de probabilidade; $\mathrm{R}^{2}=$ coeficiente de determinação; $\mathrm{CV}(\%)=$ coeficiente de variação

No P1, a relação entre as variáveis foi preferencialmente linear, exceção para altura das plantas que não houve efeito significativo. A variação dos parâmetros foi 
desprezível nesse período em virtude do baixo coeficiente angular, mantendo-se os valores médios de $130 \mathrm{~g}$ de $\mathrm{M}, 0,30 \mathrm{~m}^{2}$ de $\mathrm{AF}, 0,022 \mathrm{~m}$ de $\mathrm{D}$ e $0,254 \mathrm{~m}$ de $\mathrm{H}$. Esse fato pode estar relacionado ao período de adaptação das plantas às condições de plantio.

No P2 e P3, o efeito da irradiância ficou mais evidente. O crescimento da massa seca, da área foliar, do diâmetro da haste principal e da altura das plantas aumentou com a irradiância atingindo valores máximos $\left(y_{\max }\right)$ em diferentes irradiâncias $\left(x\right.$ para $y_{\max }$ ).

Os valores de irradiância relativa (Ir-\%) que maximiza o crescimento aumentaram com a idade das plantas de 58,5 para $73,2 \%$, para a acúmulo de massa seca da parte aérea; de 66,5 para $89,4 \%$, para área foliar total; de 64,1 para $65,6 \%$, para o diâmetro da haste principal e de 51,9 para 58,9 para altura das plantas, no P2 e P1, respectivamente (Figura 9 e 10).

As maiores respostas da Ir com o crescimento das plantas ocorreram no acúmulo da massa seca da parte aérea e na área foliar; e menores na altura das plantas. O diâmetro manteve seu valor máximo quase constantes independente do período de crescimento, em torno de $64 \%$. Os maiores aumentos Ir para área foliar chegou a valores próximos da saturação. Isso ocorreu devido à contribuição da área foliar dos perfilhos em média de 15 a 30\% da área foliar da haste principal (Figura 11). Entretanto esse fato não repercutiu na mesma proporção no acúmulo de massa seca devido à redução da altura e do diâmetro em altas Ir. As alterações na altura e na área foliar podem ser consideradas sinalizadoras de mudança na disponibilidade de luz para o açaizeiro.

O aumento da resposta das plantas a irradiância com a idade do açaizeiro, favoreceu os sistemas mais a pleno sol. A faixa ótima de Ir para o crescimento do açaizeiro variou de $52 \%$ a $67 \%$ no $\mathrm{P} 2$ e de $60 \%$ a $73 \%$ no $\mathrm{P} 3$, destacando as fileiras distanciadas a $5,5 \mathrm{~m}$ e $9,5 \mathrm{~m}$, e $9,5 \mathrm{~m}$ a $15,5 \mathrm{~m}$ da seringueira. 

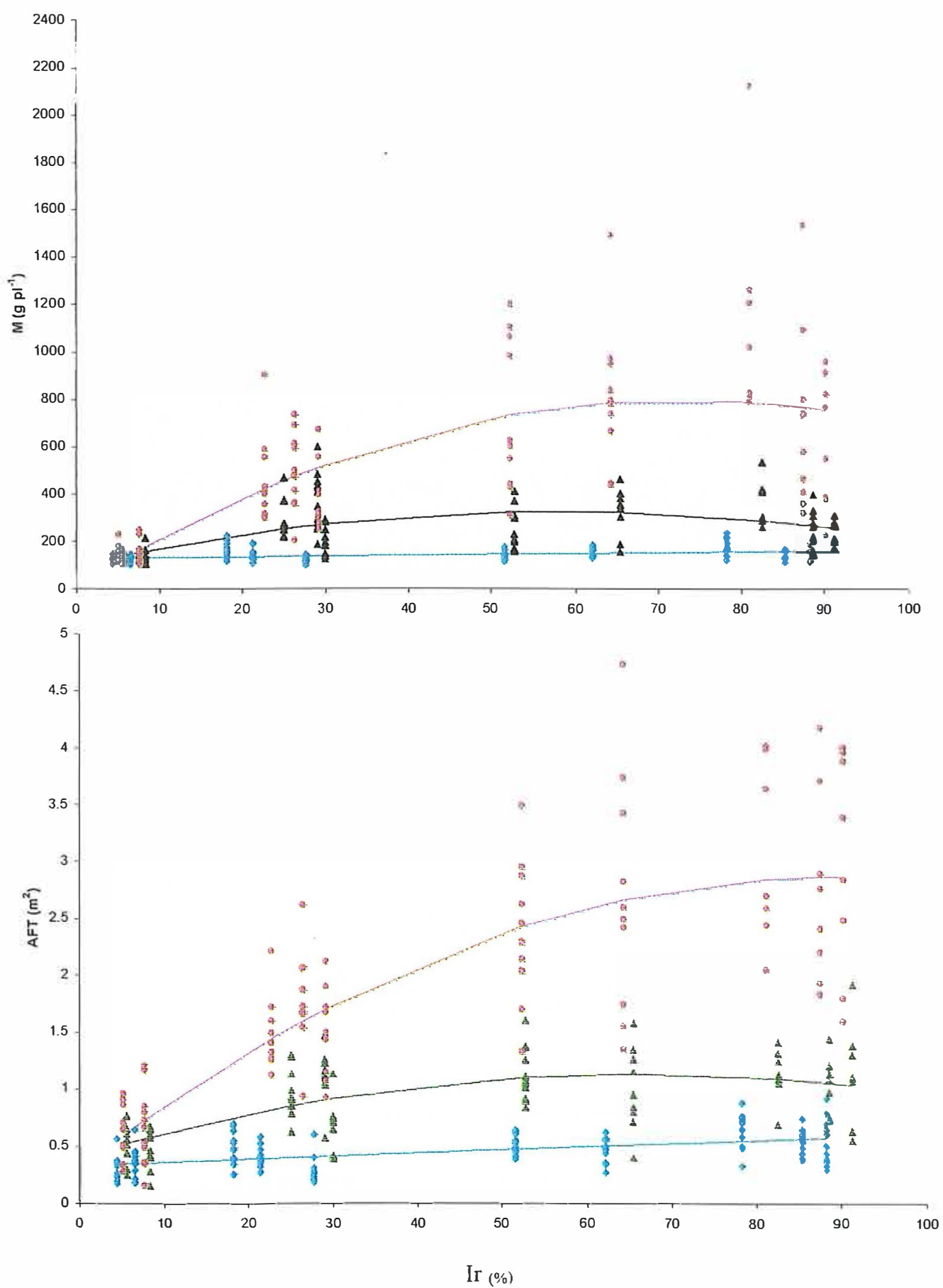

Figura 9 - Produção de massa seca da parte aérea e área foliar total do açaizeiro e irradiância acumulada em três períodos de crescimento: P1 (-), P2(-), e P3 (-) 

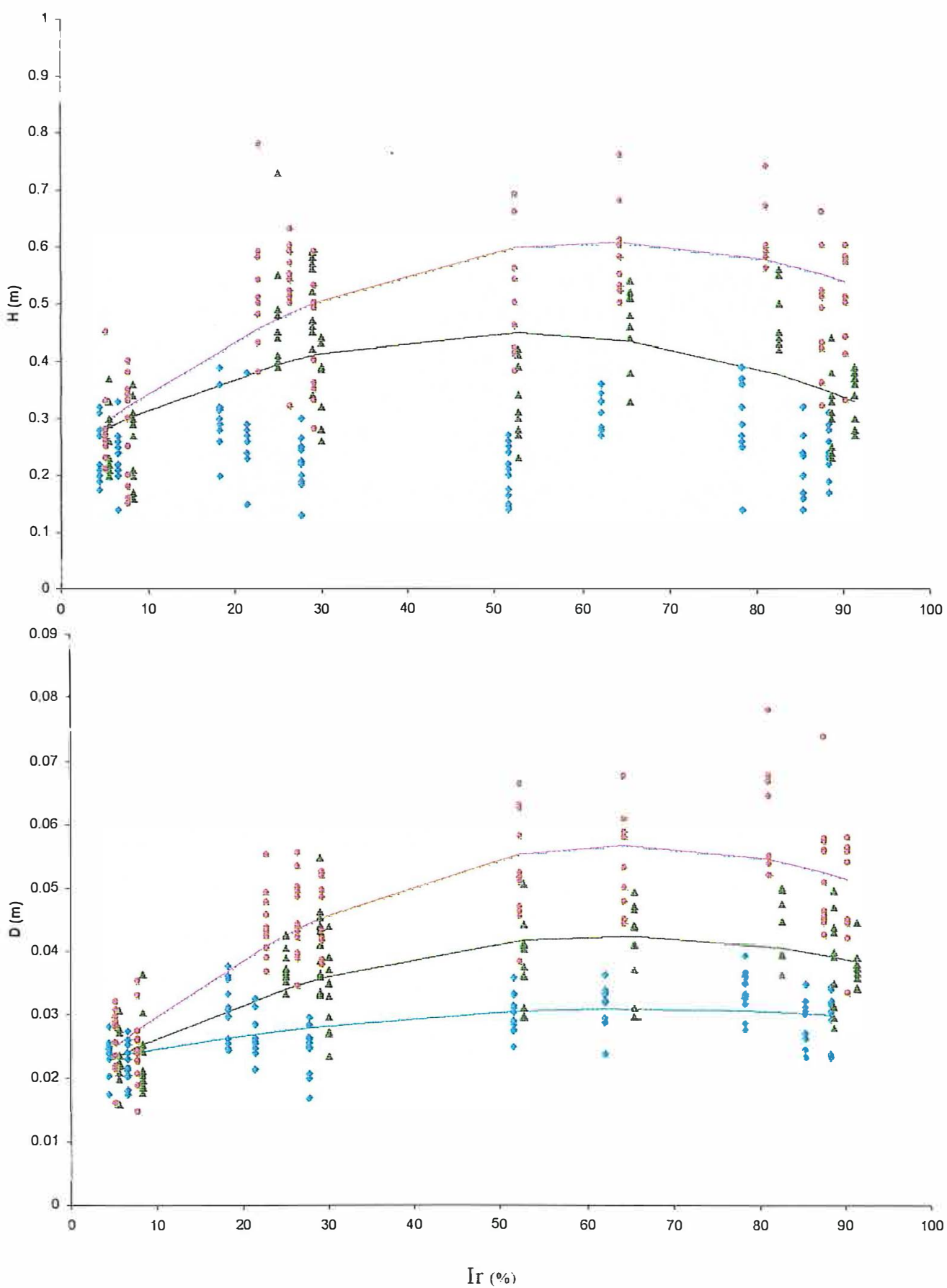

Figura 10 - Altura e diâmetro da haste principal do açaizeiro e irradiância acumulada em três períodos de crescimento: P1 $(-), \mathrm{P} 2(-)$, e P3 $(-)$ 

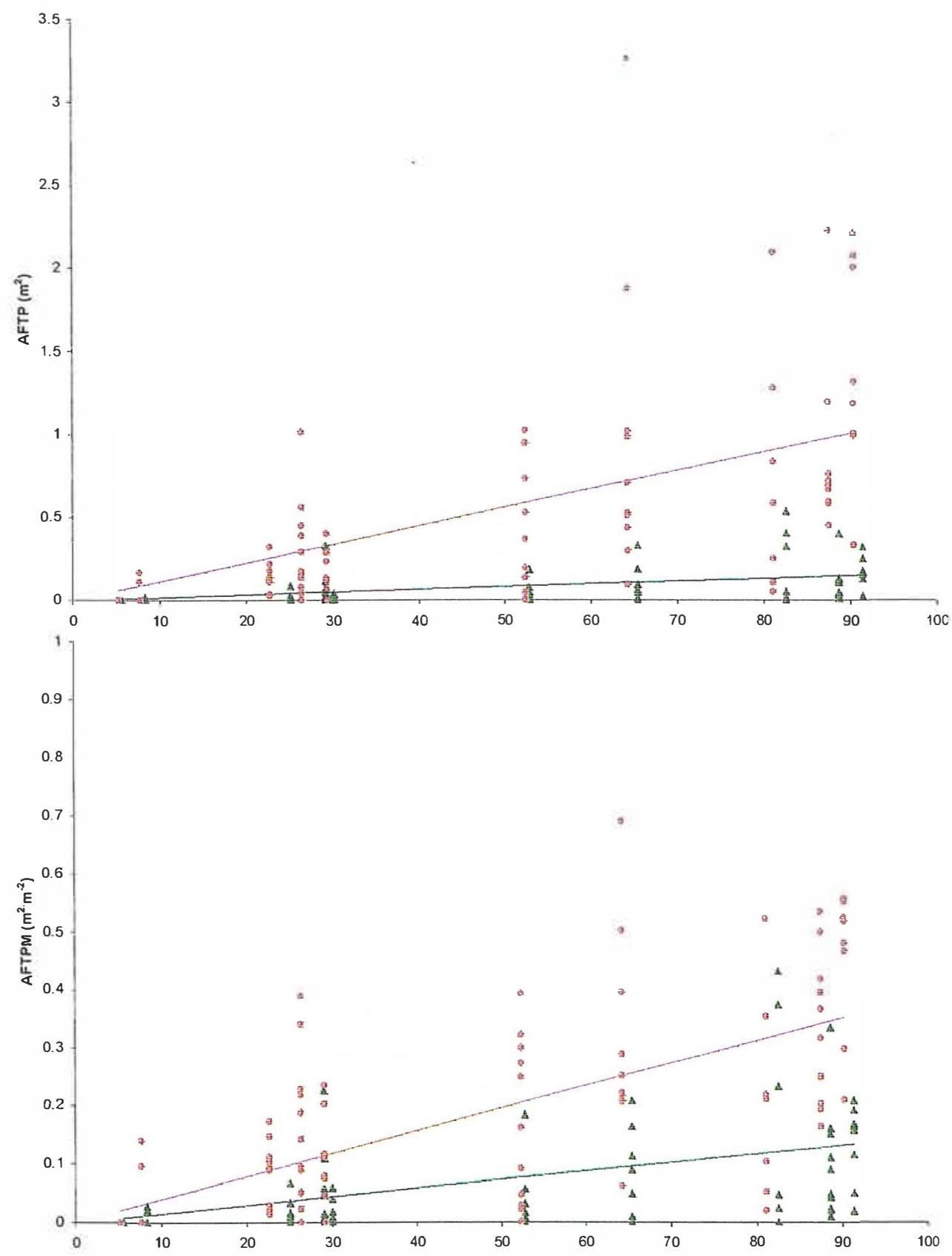

$\operatorname{Ir}(\%)$

Figura 11 - Área foliar dos perfilhos (AFP) e área foliar dos perfilhos pela área foliar da haste principal (AFPM) do açaizeiro e irradiância acumulada em três períodos de crescimento: P1 (-), P2(-), e P3 $(-)$ 


\subsubsection{Taxas de crescimento}

$\mathrm{O}$ efeito dos períodos nas taxas de crescimento foi significativo $(p<0,001)$ e variou entre os sistemas agroflorestais. A taxa de crescimento cresceu positivamente ao longo do tempo com variações entre os períodos de crescimento para os diversos ambientes agroflorestais (Figura 12). O excesso de sombreamento foi limitante paras as plantas $\mathrm{CAC}_{1 \mathrm{e} 2}$ que apresentaram variações despreziveis. Os maiores ganhos em crescimento ocorreram nas plantas da transeção das fileiras do açaizeiro com a fileira da seringueira, destacando-se a fileira a $15,5 \mathrm{~m}$. As fileiras a $23,5 \mathrm{~m}$ e $33,5 \mathrm{~m}$ apresentaram maiores ganhos somente no P3, sendo prejudicadas pelo excesso de irradiância principalmente no $\mathrm{P} 2$; ao contrário das plantas sob seringueira que foram beneficiadas no P2 com o aumento da irradiância.

\subsubsection{Taxa de crescimento absoluto (TCA)}

A TCA variou significativamente de $50,47 \mathrm{~g} \mathrm{pl}^{-1}, 108,58 \mathrm{~g} \mathrm{pl}^{-1}$ e $301,46 \mathrm{~g} \mathrm{pl}^{-1}$ nos períodos P1, P2 e P3, respectivamente. A tendência de aumento da TCA para o açaizeiro ocorreu nos diversos ambientes, exceto para as plantas $\mathrm{CAC}_{\mathrm{lez}}$. Os maiores ganhos ocorreram para as plantas a 15,5 m da seringueira no $\mathrm{Pl}$ e $\mathrm{P} 3,102,63 \mathrm{~g} \mathrm{pl}^{-1}$ e 768 $\mathrm{g} \mathrm{pl}^{-1}$, respectivamente. No P2 as plantas $\mathrm{SER}_{2}$ resultaram na maior TCA, 221,21 $\mathrm{g} \mathrm{pl}^{-1}$, não diferindo das plantas a $15,5 \mathrm{~m}, 9,5 \mathrm{~m}$ e $5,5 \mathrm{~m}$ e $\mathrm{SER}_{1}$. As plantas sob cacaueiro apresentaram valores menores de TCA em todos os períodos, em torno de $20 \mathrm{~g} \mathrm{pl}^{-1}$ (Figura 12).

\subsubsection{Taxa de crescimento relativo (TCR)}

A TCR apresentou níveis crescentes de $0,39 \mathrm{~g} \mathrm{~g}^{-1}, 0,47 \mathrm{~g} \mathrm{~g}^{-1}$, e de $0,63 \mathrm{~g} \mathrm{~g}^{-1}$ no P1, P2 e P3, respectivamente. Os ganhos em TCR ocorreram em todos os sistemas, exceto para os sistemas $\mathrm{SER}_{\mathrm{le} 2}$ e $\mathrm{CAC}_{\mathrm{le} 2}$, que tiveram redução no $\mathrm{P} 3$ e no $\mathrm{P} 2$, respectivamente (Figura 12).

As plantas a $15,5 \mathrm{~m}$ de distância das seringueiras apresentaram maiores TCR no P1 e P3, 0,70 $\mathrm{g} \mathrm{g}^{-1}$ e $1,08 \mathrm{~g} \mathrm{~g}^{-1}$, não diferindo das plantas a 9,5m e da $\mathrm{SER}_{1}$ no P1 e das plantas $5,5 \mathrm{~m}, 23,5 \mathrm{~m}, 9,5 \mathrm{~m}$ e $33,5 \mathrm{~m}$ no $\mathrm{P} 3$. No $\mathrm{P} 2$, as plantas $\mathrm{SER}_{2}$ apresentaram valores 
máximos de $0,90 \mathrm{~g} \cdot \mathrm{g}^{-1}$, não diferindo das plantas a $5,5 \mathrm{~m}, 9,5 \mathrm{~m}, 15,5 \mathrm{~m}$, e das plantas $\mathrm{SER}_{1}$. As plantas do $\mathrm{CAC}_{\mathrm{le} 2}$ apresentaram menores valores de TCR, variando de $0,20 \mathrm{~g}$ $\mathrm{g}^{-1}$ no P1 e estabilizando em $0,14 \mathrm{~g} \mathrm{~g}^{-1}$ no P2 e 3 .

\subsubsection{Taxa de assimilação líquida (TAL)}

A TAL manteve-se constante em $149 \mathrm{~g} \mathrm{~m}^{-2}$ no P1 e P2, aumentando, significativamente $(\mathrm{P}<0,0001)$, para $183 \mathrm{~g} \mathrm{~m}^{-2}$ no $\mathrm{P} 3$. Não houve um padrão único de variação entre os sistemas nos períodos. A TAL reduziu para as plantas sob dossel das árvores e aumentou para as plantas na transeção com a fileira da seringueira; exceção para as plantas no sistema $\mathrm{SER}_{2}$ que tiveram aumento da TAL no $\mathrm{P} 2 \mathrm{e}$ para as plantas a 15,5m e 33,5 m da seringueira que tiveram redução no mesmo período (Figura 13).

A TAL máxima foi de $254 \mathrm{~g} \mathrm{~m}^{-2}$ para açaizeiro a $15,5 \mathrm{~m}$ da seringueira no P1, não diferindo (Tukey; $\mathrm{p}<0,05$ ) das plantas a $9,5 \mathrm{~m}$ e dentro do dossel da seringueira; no P2 foi de $307,84 \mathrm{~g} \mathrm{~m}^{-2}$ para o açaizeiro dentro do dossel da seringueira, não diferindo das plantas a $15,5 \mathrm{~m}, 9,5 \mathrm{~m}$ e da seringueira; e no P3, a TAL máxima foi $405,74 \mathrm{~g} \mathrm{~m}^{-2}$ para o açaizeiro a $15,5 \mathrm{~m}$ da seringueira, não diferindo das plantas a $9,5 \mathrm{~m}$. As plantas sob cacaueiro apresentaram as menores taxas $81,9 \mathrm{~g} \mathrm{~m}^{-2}, 22,49 \mathrm{~g} \mathrm{~m}^{-2}$, e $33,42 \mathrm{~g} \mathrm{~m}^{-2}$ no P1, P2 e P3, respectivamente.

\subsubsection{Razão de área foliar (RAF)}

A RAF aumentou de $0,002708 \mathrm{~m}^{2} \mathrm{~g}^{-1}, 0,003467 \mathrm{~m}^{2} \mathrm{~g}^{-1}$ e $0,003836 \mathrm{~m}^{2} \mathrm{~g}^{-1}$ no P1, P2 e P3 respectivamente. A tendência de aumento se deu em todas as plantas exceto a $15,5 \mathrm{~m}$ da seringueira que não variou e a 5,5m que manteve estável após o P2. As plantas a 33,5 $\mathrm{m}$ da seringueira mantiveram os maiores valores em todos os períodos, $0,0032 \mathrm{~m}^{2}$ $\mathrm{g}^{-1}(\mathrm{P} 1), 0,0043 \mathrm{~m}^{2} \mathrm{~g}^{-1}(\mathrm{P} 2)$ e $0,0050 \mathrm{~m}^{2} \mathrm{~g}^{-1}(\mathrm{P} 3)$, não diferindo das plantas a $23,5 \mathrm{~m}, 5,5 \mathrm{~m}$ e $15,5 \mathrm{~m}$ da seringueira no $\mathrm{P} 1$; das plantas a $5,5 \mathrm{~m}, 23,5 \mathrm{~m}$ no $\mathrm{P} 2$; e das plantas a $23,5 \mathrm{~m}$, $5,5 \mathrm{~m}$ da seringueira e sob cacaueiro, guarantã e leucena, no P3. (Figura 13) 

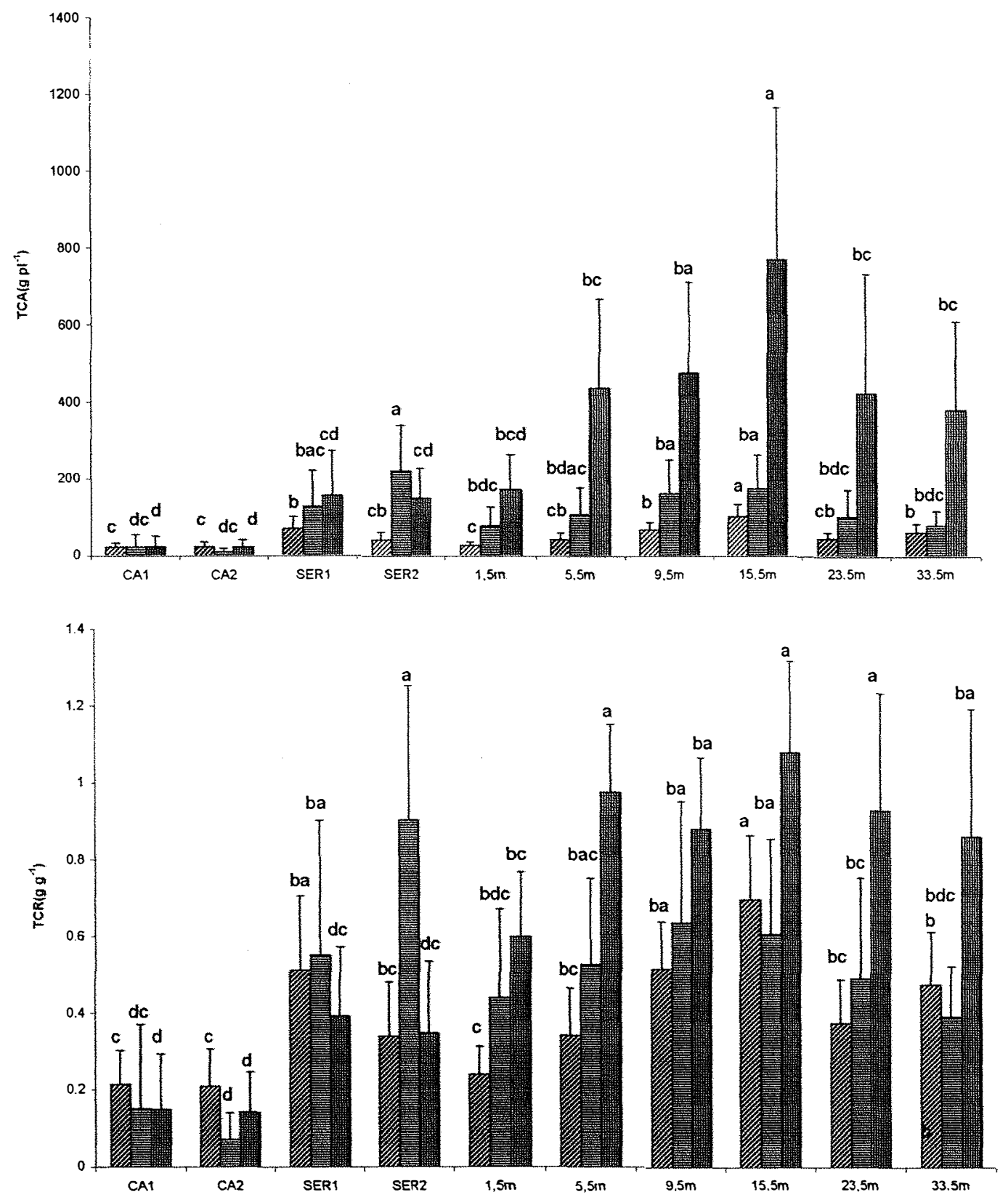

Figura 12 - Taxa de crescimento absoluto (TCA) e relativo (TCR) do açaizeiro nos três períodos de crescimento e nos diferentes ambientes agroflorestais; P1(barra inclinada); P2 (barra horizontal); e P3 (barra vertical), $\mathrm{CA}_{1 \mathrm{e} 2}$ - açaizeiro sob

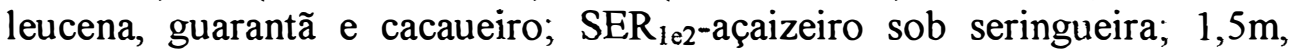
$5,5 \mathrm{~m}, 9,5 \mathrm{~m}, 15,5 \mathrm{~m}, 23,5 \mathrm{~m}$ e $33,5 \mathrm{~m}$ são as distâncias das fileiras de açaizeiro a partir da fileira de seringueira. Representações dos valores médios seguidos de mesma letra não diferem entre colunas de mesmo formato, pelo teste de Tukey a 5\% de probabilidade 


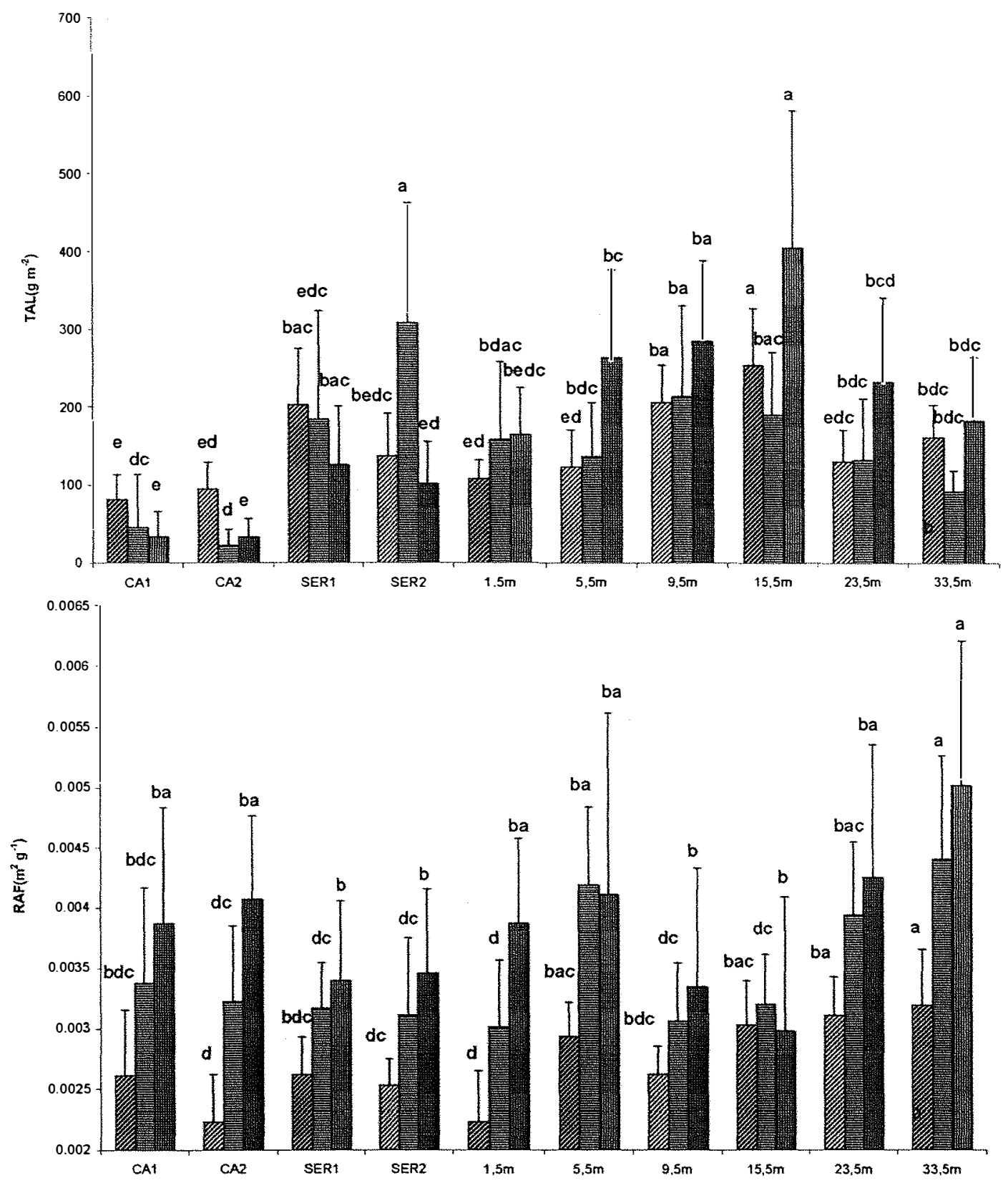

Figura 13 - Taxa de assimilação líquida(TAL) e razão de área foliar(RAF) do açaizeiro nos três períodos de crescimento e nos diferentes ambientes agroflorestais; P1(barra inclinada); P2 (barra horizontal); e P3 (barra vertical), $\mathrm{CA}_{1 \mathrm{e} 2}$ açaizeiro sob leucena, guarantã e cacaueiro; SER $_{1 \mathrm{e} 2 \text {-açaizeiro sob }}$ seringueira; $1,5 \mathrm{~m}, 5,5 \mathrm{~m}, 9,5 \mathrm{~m}, 15,5 \mathrm{~m}, 23,5 \mathrm{~m}$ e $33,5 \mathrm{~m}$ são as distâncias das fileiras de açaizeiro a partir da fileira de seringueira. Representações dos valores médios seguidos de mesma letra não diferem entre colunas de mesmo formato, pelo teste de Tukey a $5 \%$ de probabilidade 
As plantas que cresceram sob irradiância menor que $10 \%$ e maior que $80 \%$ apresentaram mais investimento em área foliar por $\mathrm{g}$ de massa seca produzida. As plantas sob seringueira e a 9,5 $\mathrm{m}$ e $15,5 \mathrm{~m}$ foram as que menos investiram em área foliar, $0,0030 \mathrm{~m}^{2} \mathrm{~g}^{-1}$

\subsubsection{Eficiência de uso da radiação disponível (RUEd)}

A RUEd variou entre os períodos de crescimento e entre os sistemas agroflorestais conforme verificado na Figura 14. A RUEd apresentou aumento médio significativo com o crescimento das plantas de $0,048 \mathrm{~g} \mathrm{MJ}^{-1} \mathrm{~m}^{-2}$ no P1, para $0,088 \mathrm{~g} \mathrm{MJ}^{-}$ ${ }^{1} \mathrm{~m}^{-2}$ no P2 e 0,192 $\mathrm{g} \mathrm{MJ}^{-1} \mathrm{~m}^{-2}$ no P3. Esse aumento ocorreu em todos os sistemas, exceto no CAC que reduziu no $\mathrm{P} 2$ e aumentou no P3, porém mantendo valores mais baixos aos encontrados no $\mathrm{P} 1$.

As plantas que cresceram sob dossel das árvores apresentaram maior RUEd no P1. Esse padrão foi mantido nos demais períodos para as plantas sob seringueira que apresentaram os maiores valores de RUEd em todos os períodos, não diferindo das plantas distanciadas a $15,5 \mathrm{~m}$ da seringueira no $\mathrm{P} 3$.

No intervalo de irradiância estudado a RUEd decresceu linearmente com o aumento da irradiância incidente no topo das copas dos açaizeiros no P1. Já nos dois outros períodos a RUEd teve valor ótimo em função da irradiância incidente no topo das copas dos açaizeiros (Figura 14). A irradiância que maximiza a RUEd aumentou com a idade das plantas. As plantas foram mais eficientes no uso da radiação disponível em condições de irradiância relativa disponível no topo das copas de $10 \%, 48 \%$ e $50 \%$ no P1, P2 e P3, respectivamente. Evidenciando a capacidade adaptativa das palmeiras ao ambientes de maior irradiância com o crescimento, conforme descrito (Svenning,2001). 


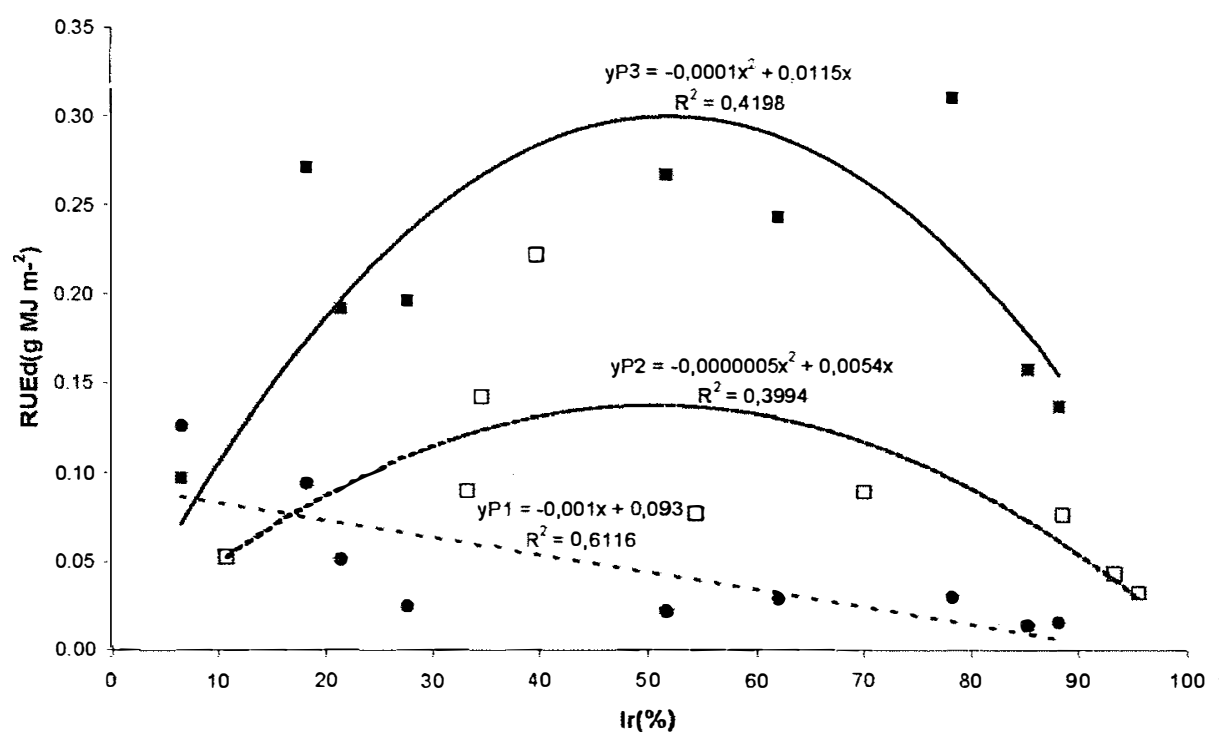

Figura 14 - Eficiência do uso da radiação disponível (RUEd) no P1 $\left(^{\bullet}\right.$ ), P2 ( $\square$ ) e P3 ( - ) em função da irradiância relativa incidente no topo das copas dos açaizeiros. 


\section{DISCUSSÃO}

Devido à sua importância econômica no agronegócio do palmito e na produção de polpa de frutas, o cultivo do açaizeiro encontra-se além do seu local regional de ocorrência. Há registros de ocorrência nos estados da Bahia e de São Paulo, preferencialmente em áreas com boa distribuição de chuva. As condições climáticas vigentes no local e durante o estudo aqui desenvolvido diferem bastante daquelas na área de ocorrência natural da palmeira.

O período frio e seco que ocorreu no P2 causou um atraso na fase inicial de crescimento do açaizeiro. Assim, as maiores taxas em crescimento ocorreram depois do primeiro ano do plantio. A irrigação e o sombreamento das mudas foram importantes para complementar o suprimento de água, que é insatisfatório para a planta no local do experimento, e para atenuar as elevadas disponibilidade de irradiância e a demanda transpiratória.

\subsection{Massa seca da parte aérea, área foliar, altura e diâmetro da haste principal do açaizeiro}

A massa seca da parte aérea aumentou gradualmente com o aumento da irradiância apresentando um ótimo em intensidades de irradiância inferior aos registrados mais a pleno sol. Como esperado, as resposta à irradiância aumentou com a idade das plantas. No primeiro ano, a faixa ótima de irradiância para o crescimento do açaizeiro foi de $58 \%$, enquanto que seis meses depois, a demanda foi de $73 \%$ para o maior acúmulo de massa seca. Estudos sobre crescimento de mudas de coqueiro (Gopinathan \& Nair,1982) e palmeira juçara (Nodari et al., 1999), com sombra artificial, apontam níveis de $50 \%$ de sombra para o melhor crescimento das palmeiras no primeiro ano. Kahn \& Granville (1992), ressaltam o aumento crescente da demanda de irradiância 
para as palmeiras com as fases de crescimento. $\mathrm{O}$ autor explica a menor ocorrência de palmeiras arborescentes em matas fechadas devido ao progressivo nível de luz cada vez mais alto necessário para as palmeiras caulescentes desenvolverem a estrutura caulinar e multicaulinar, isto é, passarem da fase juvenil para a fase adulta.

Valores muito próximos aos encontrados aqui para o crescimento inicial do açaizeiro foi verificado por Hamp (1991) nas florestas de várzea, Ilha Combú (Acará PA), local de ocorrência natural dos acaizeiros. Nesse estudo a irradiância medida ao nível do solo variou de $26 \%$ a $47 \%$, em áreas manejadas e não manejadas de açaizais nativos, respectivamente. Isso significa que da irradiância disponível, 50 a $75 \%$ foi interceptado pelas palmeiras e que $50 \%$ e $25 \%$ foi transmitida para o desenvolvimento de jovens palmeiras. Valores estes, bem acima dos encontrados em floresta virgem de terra firme, que chega a $1 \%$.

Recomendações de manejo apontam a importância da sombra na fase de estabelecimento das palmeiras. $\mathrm{Na}$ introdução de palmito em áreas florestadas recomenda-se fazer um desbaste, eliminando-se toda a vegetação de pequeno porte, porém tendo-se o cuidado de deixar um número adequado de árvores para proporcionar um sombreamento de $40 \%$. Entretanto seria interessante, após certa idade receber maior luminosidade ou até luz direta. As palmeiras isoladas ou sem influência das árvores de porte elevado, diminuem o crescimento em altura e aumentam em diâmetro, possibilitando maior rendimento de palmito e de fruto (Nogueira,1980).

$\mathrm{O}$ aumento crescente da irradiância para o crescimento foi também encontrado para o pinheiro silvestre (Abies alba Mill), uma das espécies arbóreas mais tolerantes à sombra da Europa. Neste estudo foi registrado um aumento de demanda de 5\% de irradiância incidente, aos dois anos de idade, para 75 \%, aos 15 anos (Jaworski, 1995, citado por Robakowski et al., 2003).

Dos parâmetros de planta, a altura e o diâmetro da haste principal apresentaram menores variações com o aumento crescente da irradiância, comparado com a área foliar e a massa seca da parte aérea. A massa seca da parte aérea, a área foliar total, o diâmetro e a altura da haste principal foram menores na sombra, $10 \%$ de $\mathrm{Ir}$, e maiores sob $89 \%$, 
$73 \%, 64 \%$ e $51 \%$ de Ir. As plantas mais a pleno sol apresentaram o menor crescimento na transeção, entretanto foram superiores às plantas que cresceram sob as árvores.

\subsection{Análise do crescimento}

A massa seca da parte aérea das plantas no momento do plantio era $99,4 \mathrm{~g}$ por planta. Após os três períodos de crescimento, aumentou $360 \mathrm{~g}$ por planta sob máxima irradiância e apenas $52 \mathrm{~g}$ na sombra máxima. Os maiores ganhos ocorreram a $20 \%$ de sombra, no sistema $15,5 \mathrm{~m}$ de distância da borda da seringueira, com aumento de $1000 \mathrm{~g}$ por planta até o final do experimento. Essa tendência foi mantida nos períodos com maior disponibilidade de fatores de crescimento, P1 e P3. No P2, os ganhos nas posições intermediárias da transeção $(9,5 \mathrm{~m}$ e $15,5 \mathrm{~m})$ e nas plantas sob o dossel de seringueira (SER) foram equivalentes.

As condições de baixa disponibilidade de água no solo e baixa temperatura no $\mathrm{P} 2$, não foram limitantes para as plantas sob seringueira (SER). O aumento de irradiância nessa posição advinda da intensa desfolha das seringueiras, relativamente maior que nas demais posições, aliado a um gradiente térmico menor e a uma demanda transpiratória mais compatível com a disponibilidade hídrica do solo, provavelmente compensou as condições desfavoráveis ao crescimento no período refletindo em maiores ganhos de massa seca nesse sistema.

A demanda evapotranspiratória quase duas vezes maior para as plantas na posição de $33 \mathrm{~m}$, aliado ao baixo suprimento hídrico, pode ter causado um estresse hídrico moderado refletindo em ganhos de menores proporções. As folhas lançadas no período seguinte apresentaram folíolos de menor comprimento e maior adensamento na ráquis, típico de sintoma de deficiência de boro causa do pela falta de água. Esse sintoma foi generalizado entre as plantas nos $33 \mathrm{~m}$. Já nas posições de 15,5 e 23,5, com alguma atenuação da insolação, o crescimento dos açaizeiros em P2 foi igual ao alcançado nas plantas sob seringueira (SER).

Estudo sobre as relações hídricas do açaizeiro, em condições naturais com plantas adultas e em casa de vegetação com plantas jovens, são conclusivos quanto aos mecanismos de ajuste fisiológico nas condições de estresse hídrico causado pelo excesso 
e falta de água no solo (Calbo \& Moares, 2000; Carvalho et al., 1998). Dentre os mecanismos os autores citam: manutenção da difusão gasosa mesmo com o potencial hídrico alto (-2,0 $\mathrm{MPa})$ teor relativo de água nos tecidos foliares elevado, atingindo o valor mínimo de $92 \%$, com potencial hídrico correspondente a $-2,0 \mathrm{MPa}$ às $12 \mathrm{~h}$; e o aumento do potencial osmótico das folhas em estresse moderado. Carvalho et al. (1998) relatam que os estômatos respondem mais às variações da radiação incidente que aos prováveis distúrbios na absorção de água, causados pelo alagamento na época chuvosa ou pela quebra de raízes finas superficiais na época seca.

O ganho em massa seca foi crescente entre os períodos de crescimento para as plantas na transeção, principalmente nos períodos de maiores disponibilidades de água no solo, temperatura, e irradiância. Isso foi mais evidente no P3 com o aumento da TAL, após um período de estagnação.

A maior área foliar por grama de massa seca produzida na parte aérea (RAF) encontrada nas plantas mais iluminadas e nas plantas mais sombreadas, mas por outro lado, com a menor produção em grama de massa seca por área foliar produzida (TAL) nessas mesmas posições, podem denotar resultados contraditórios. Entretanto, algumas evidências podem ajudar a explicá-los.

$\mathrm{Na}$ condição de sombreamento mais intenso (CAC), ocorre adaptação para aumentar a área foliar por unidade de massa foliar, aumentando a área foliar específica. Isso ocorre porque há estimulo em aumentar a superficie de interceptação de irradiância com o mínimo de alocação de matéria seca para folhas, numa condição de falta de luz. A queda da TAL na posição de sombreamento mais intenso (CAC), ao longo dos três períodos de crescimento, e menor entre os tratamentos, indica que a condição de $10 \%$ de irradiância pode estar próxima ou abaixo do ponto de compensação. Essa condição provavelmente irá causar atraso no desenvolvimento dessas plantas. Já na posição de maior disponibilidade de luz $(33,5 \mathrm{~m})$, o estímulo ao perfilhamento acrescentou até $30 \%$ na área foliar da haste principal. Entretanto, a maior área foliar não refletiu em aumento proporcional na assimilação de carbono, uma vez que a TAL diminuiu nessa posição. Isso pode ser explicado pela menor eficiência do uso da radiação nessas condições. 
Adicionalmente, podemos considerar que o perfilhamento como processo que participou da modificação da TAL. Os perfilhos são brotações da base das plantas, pouco enraizados nessa fase, podendo ser considerados fortes drenos com dispêndio excessivo de fotoassimiliados para seu crescimento e que favorecem a perda de água aumentando a superficie transpiratória sem a respectiva superficie de absorção de água pelas raízes. Provavelmente, tudo isso resultou em menores aumentos de massa seca por área foliar. Somado a isso, o estresse hídrico na fase de estabelecimento das palmeiras, pode ter contribuído às menores taxas de assimilação liquida.

Em pinheiros silvestres a produção de área foliar por massa total foi correlacionada negativamente com biomassa total da planta (Robakowski et al., 2003), o inverso do observado no açaizeiro, visto que menores acúmulos de massa seca ocorreram nas condições de alto sombreamento e alta irradiância.

A máxima eficiência do uso da radiação disponível ( $R U E d=0,31 \mathrm{~g} \mathrm{MJ} \mathrm{m}^{-2}$ ) esteve bem abaixo das encontradas para as culturas anuais $\left(1,8 \mathrm{~g} \mathrm{MJ}^{-1}\right)$ e para outras palmeiras como o coqueiro $\left(0,8-1,4 \mathrm{~g} \mathrm{MJ}^{-1}\right.$ ) (Jayasekara, citado por Jayasekara \& Jayasekara, 1995) e o dendezeiro, 1,5 $\mathrm{g} \mathrm{MJ}^{-1}$ (Corley, citado por Jayasekara \& Jayasekara, 1995). O método adotado para o cálculo da RUEd (g pl-1 por MJ m ${ }^{-2}$ irradiância disponível) difere do padrão da bibliografia do assunto $\left(\mathrm{g} \mathrm{m}^{-2}\right.$ por $\mathrm{MJm}^{-2}$ irradiância interceptada). Pelo método padrão poderiam ser esperados valores de até o dobro dos encontrados. Mesmo assim, esses últimos seriam inferiores àqueles publicados para plantas adultas de açaizeiro. Pode-se considerar que a RUEd seja naturalmente baixa em plantas em fase juvenil, como no presente estudo. De qualquer forma, justifica-se aprimorar estudos futuros nesse assunto, uma vez que a RUE é um excelente indicador de crescimento, de resposta das plantas ao ambiente e de eficiência de sistemas de produção. Raros são os trabalhos que estimam a eficiência do uso da radiação em plantas na fase inicial de crescimento, em função da irradiância interceptada principalmente em culturas anuais (Sinclair \& Muchow, 1999).

A RUEd aumentou com a idade, dobrando seus valores a cada período de crescimento. Entretanto o ganho de massa seca por planta em função da irradiância 
disponível no CAC foi tão pequeno que levou a redução da RUEd das palmeiras nesse sistema com a idade das plantas.

A variação da RUEd diferiu entre os sistemas em função da irradiância disponível e da idade das plantas. As plantas a $10 \%$ da irradiância natural (CAC) converteram energia luminosa em massa seca oito vezes mais eficientemente que as plantas na posição mais iluminada $(33,5 \mathrm{~m})$ nos primeiros seis meses de plantio. Entretanto com a adaptação das plantas às condições de maiores intensidades de irradiância, a RUEd aumentou para as plantas com maiores intensidades de irradiância apresentando um ótimo em torno de 50\% de irradiância relativa disponível.

A RUEd, assim como a TAL, apresentaram menores valores para as plantas que cresceram sob as condições extremas de irradiância e maiores valores para as plantas com intensidades de irradiância intermediária variando de $20 \%$ a $80 \%$. O sombreamento excessivo nas condições de $10 \%$ de irradiância e o possível estresse hídrico, nas condições de irradiância acima de $80 \%$ podem explicar esse desempenho.

$\mathrm{O}$ estresse hídrico, dentre outros fatores, provoca alterações na capacidade fotossintética durante o ciclo da planta podendo causar mudanças diretas na RUE (Sinclair \& Muchow, 1999; Black \& Ong, 2000). Outros fatores também apontados pelos autores são as diferentes intensidades de radiação ou da proporção da radiação direta e difusa. No presente estudo, esses dois aspectos podem ter concorrido para favorer as plantas nos sistemas sob seringueira e nas distâncias até $15,5 \mathrm{~m}$.

\subsection{Considerações finais}

$\mathrm{O}$ açaizeiro apresentou adaptações às condições de plantio diferentes daquelas de seu local de origem. Entretanto algumas considerações de manejo podem ser destacadas para o cultivo do açaizeiro em monocultico ou em consórcio com outras espécies, em condições de climáticas diferentes das condições do local de origem. O sombreamento e a irrigação, na fase inicial de crescimento, são fundamentais para um bom desempenho da palmeira. Isso implica que o sombreamento provisório no primeiro ano pode ser útil para o estabelecimento da palmeira, minimizando o estresse causado pelo excesso de radiação, além de reduzir os custos iniciais de implantação da cultura e trazer retorno 
econômico pela produção da cultura consorte. Nesse caso uma espécie anual, como a mandioca, pode consociada com o açaizeiro, plantando-a antecipadamente de forma que sua copa propicie o sombreamento provisório e parcial para o plantio das mudas de açaízeiro.

A irrigação foi de extrema importância para a palmeira mesmo com o plantio tendo ocorrido no verão chuvoso, visto que os veranicos são comuns nesse período e podem agravar o estresse causado pelo transplantio, principalmente em condições de alta irradiância relativa. Ademais o período de baixa disponibilidade de água no solo no inverno levando a um déficti hídrico para as plantas pode ser limitante para o crescimento das palmeiras na fase inicial de crescimento, caso não haja um suprimento hídrico por irrigação.

A adaptação do açaizeiro a uma grande faixa de irradiância, de $20 \%$ à $80 \%$, permite diversas composições e desenhos de sistemas cultivados para sua produção. Deve ser ressaltado que as espécies de dossel superior escolhidas para compor os sistemas agroflorestais devem ser manejadas de forma a proporcionar um aumento crescente de irradiância para as palmeiras com seu aumento de idade. 


\section{CONCLUSÃO}

O açaizeiro mostrou uma grande plasticidade no crescimento e na eficiência do uso da radiação disponível em função das intensidades de irradiância. $\mathrm{O}$ açaizeiro apresentou a capacidade de adaptar-se a uma faixa grande de irradiância que vai desde ao intenso sombreamento até a intensidades altas de irradiância. $\mathrm{O}$ crescimento do açaizeiro aumentou com o incremento da disponibilidade de irradiância até um ótimo que ocorre numa irradiância relativa menor que $80 \%$. A irradiância relativa ótima para o crescimento aumentou com incremento da idade dos açaizeiros. 


\section{REFERÊNCIAS BIBLIOGRÁFICAS}

ANDERSON, A.B. Use e management of native forests dominated by açaí palm (Euterpe oleracea Mart) in the Amazon estuary. Advances Economic Botany, v.6, p. 144-154, 1988.

ANDERSON, A.B.; GÉLY, A., STRUDWICK; J., SOBEL, G. L.; PINTO, M. G. C. Um sistema agroflorestal na várzea do estuário Amazônico (Ilha das Onças, Município de Barcarena, PA). Acta Amazônica, v. 15, p. 195-224, 1985.

ARAUS, J. L.; HOGAN, K. P. Leaf structure and patterns of photoinhibition in two neotropical palms in clearings and forest understory during the dry season. American Journal of Botany,v.81, n. 6, p.726-738, 1994.

ATAROFF, M.; SCHWARZKOPF, T. Vegetative growth in Chamaedorea bartlingiana. Principes, v.38, n.1, p.24-32, 1994.

BAUMER, M. Agroforestry and desertification: the potencial role of agroforestry in combating desertification and environmental degradation with special reference to Africa. Wageningen: Technical Centre for Agricultural and Rural Cooperation, 1990. $250 \mathrm{p}$.

BERNARDES, M. S.; LMA, S. F. F.; TERAMOTO, E. R. et al. Recuperação do solo degradado com sistemas agroflorestais no extremo sul da Bahia. In: REUNIÃO BRASILEIRA DE MANEJO E CONSERVAÇÃO DO SOLO E DA ÁGUA, 13., Ilhéus, 2000. Anais. Ilhéus: CEPLAC/CEPEC, 2000. p.14-16.

BLACK, C.; ONG, C. Utilisation of light and water in tropical agriculture. Agricultural and Forest Meteorology, v. 104, n. 1, p.25-47, 2000.

BONAL, D. Influence of some in situ environmental factors on growth performances of Calamus caesius. Journal of Tropical Forest Science, v.9, n.3, p. 369-378, 1997. 
BOVI, M. L. A.; GODOY JÚNIOR, G.; NAGAI, V. et al. Densidade de plantio em consórcio com seringueira. Pesquisa Agropecuária Brasileira, v.25, n.7, p.1023$1039,1990$.

BROSCHAT, T. K.; DONSELMAN, H.; MCCONNELL, D. Light aclimatization in Ptychosperma elegans. Hort Science, v.24, n.2, p.267-268, 1989.

CALBO, M. E. R.; MORAES, J. A. P. V. Efeitos da eficiência de água em plantas de Euterpe oleracea (açai). Revista Brasileira de Botânica, v.23, n.3, p.225-230, 2000.

CALDEIRA, M. V. W.; CHITOLINA, P.G.; SELLE, G. L. et al. Efeito de diferentes níveis de sombreamento no palmiteiro em viveiro. Agropecuária Catarinense, v.9, n. 1, 1996.

CANNELL, M. G. R.; VAN NOORDWIJK, M; ONG, C.K. The central agroforestry hypothesis: the trees must acquire resources that the crop would not otherwise acquire. Agroforestry Systems, v.33, n. 1, p. 1-5, 1996.

CARVALHO, C. J. R.; ROMBOLD, J. NEPSTAD, D. C. et al. Relações hídricas do açaizeiro (Euterpe oleracea Mart) em mata de várzea do estuário do Amazonas. Revista Brasileira de Fisiologia Vegetal, v. 10, n.3, p.213-218, 1998.

CAUSTON, R. D.; VENUS, J. C. The biometry of plant growth. London: University College of Wales, Edward Amold, 1981. 307p.

CHAZDON, R. L. Leaf display, canopy structure, and light interception of two understory palm species. Amercan Journal of Botany, v.72, n.10, p.1493-1502, 1985.

CHAZDON, R. L.. Light variation and carbon gain in rain forest understorey palms. Journal of Ecology, v.74, n.4, p. 995-1012, 1986a

CHAZDON, R. L. Physiological and morphological basis of shade tolerance in rain forest understory palms. Principes, v.30, p.92-99, 1986b

CLEMENTE, C. R.; BOVI, M. L. A. Padronização de medidas de crescimento e produção em experimentos com pupunheira para palmito. Acta Amazônica, v.33, n.3, p.349-362, 2000. 
DEMETRIADES-SHAH, T. H.;FUCHS, M.; KANEMASU, E. T. et al. A note of caution concerning the relationship between cumulated intercepted solar radiation and crop growth. Agricultural and Forest Meteorology, v. 58, n.3/4, p.193-207, 1992.

ENRIGHT, N. J; WATSON, A. D. Population dynamics of the nikau palm, Rhopalostylis sapida (Wendl. et Drude), in a temperate forest remnant near Auckland, New Zealand. New Zealand Journal Botanic, v.30, n. 1, p. 39-43, 1992.

FNP CONSULTORIA \& COMÉCIO. Agrianual 2000: Anuário de agricultura brasileira. S. Paulo: Argos, 1999. 446 p.

GIVNISH, T. J. Adaptation to sun and shade: a whole plant perspective. Australian Journal Plant Physiology, v.15, p.63-92, 1988.

GIVNISH, T. J. On the causes of gradients in tropical tree diversity. Journal Ecology, v.87, n.2, p. 193-210, 1999.

GOLDTHORPE, C.C. A review of environmental issues in natural rubber production. Planter, v.72, n.840, p.123-139, 1996.

GOPINATHAN, R.; NAIR, R. V. Shade and moisture requirement of cocoa seedlings. In: INTERNATIONAL HORTICULTURAL CONGRESS, 21., Hamburg, 1982. Abstract Collection. Hamburg: International Society for Horticulture Science, 1982. v. 2, p. 2163 b.

GRANVILLE, J. J. Aperçu sur la structure des pneumatophores de deux especèces des sols hydromorphes en Guyane. Série Biologique, n. 23, p. 3-22, 1974

GRANVILLE, J.J. Life forms and growth strategies of Guianan palms as related to their ecology. Bulletin Institut France Etudes Andines, v. 21, p.533-548, 1992.

HAGGAR, J. P.; EWEL, J. J. Establishment, resource acquisition, and early productivity as determined by biomassa allocation patterns of three tropical tree species. Forest Science, v.41, n.4, p.689-708, 1995.

HAGGAR, J. P.; EWEL, J. J. Primary productivity and resource partitioning in model tropical ecosystems. Ecology, v.78, n.4, p.1211-1221, 1997. 
HAMMER, G. L.; WRIGHT, G. C. A theoretical analysis of nitrogen and radiation effects on radiation use efficiency in peanut. Australian Journal of Agricultural Research. v.45, n.3, p.575-589, 1994.

HAMP, R. S. A study of the factors effecting the productivy of the açai palm (Euterpe oleraceae Mart) on Combu island, near Belém, northern Brazil. London, 1991. 69p. Tesy (PHD)-University of London.

HOGAN, K. P. Photosynthesis in two neotropical palm species. Functional Ecology, n. 4 , v.2, p. 371-377, 1988.

HORIE, T.; SAKURATANI, T. Studies on crop-weather relationship model in rice, 1: Relation between absorbed solar radiation by the crop and the dry matter production. Journal Agricultural Meteorology, v.40, n.4, p.331-342, 1985.

HOWARD, S. B.; ONG, M.R.; RAO, M. R. et al. The partitioning of light and water in leucaena-maize agroforestry systems. In: SINOQUET, H.; CRUZ, P.(Ed). Ecophysiology of tropical intercropping. Paris: INRA, 1995. pt. 2, p. 123-135.

INTHAPAN, P.; FUKAI, S. Growth and yield of rice cultivars under sprinkler irrigation in south-eastern Queensland. 2. Comparison with maize and grain sorghum under wet and dry cinditions. Australian Journal of Experimental Agriculture, v.28, n.2, p. 243-248, 1988.

JARDIM, M. A. G.; ROMBOLD, J. S. Effects of adubation and thinning on açaí palm (Euterpe oleracea Mart.) fruit yield from a natural population. Boletim do Museu Paraense Emílio Goeldi, v. 10, n.2, p.283-293, 1994.

JAYASEKARA, C.; JAYASEKARABOVI, K. S. Photosynthetic characteristics of tropical three species with special reference to palms. Energy Conversion Management, v.36, n.6/9, p.919-922, 1995.

KAHN, F. Life forms of Amazonian palms in relation to forest structure and dynamics. Biotropica, v. 18, n. 3, p.214-218, 1986.

KAHN, F.; CASTRO, A. The palm community in a forest of central Amazonia, Brazil. Biotropica, v.17, n.3 p.210-216, 1985.

KAHN, F.; GRANVILLE, J. J. Palms in forest ecosystems of Amazonia. Berlin: Springer Verlag, 1992. 226p. (Ecological studies, 95). 
KAlil Filho, A N.; AlVES, J. C.; CAETANO, L. J. et al. Potencialidade de progênies de açaizeiro (Euterpe oleracea Mart.) para produção de frutos em sistemas agroflorestais na região de Manaus-AM. Pesquisa em Andamento. EMBRAPACPAAO, n.37, p.1-4. nov.1998.

LEMAIRE, G. Ecophysiological approaches to intercropping. In: SINOQUET, H.; CRUZ, P.(Ed). Ecophysiology of tropical intercropping. Paris: INRA, 1995. p.925 .

MENEZES NETO, M. A. Influência da disponibilidade de oxigênio sobre a germinação, crescimento e atividade das enzimas álcool desidrogenase e lactato desidrogenase em açaí (Euterpe oleracea Mart). Lavras, 1994. 42 p. Dissertação (Mestrado) Universidade Federal de Lavras.

MESSIER, C.; DOUCET, R.; RUEL, J. C. et al. Functional ecology of advance regeneration in relation to light in boreal forests. Canadian Journal Forestry Research, v.29, n.6, p.812-823, 1999.

MONSI, M.; SAEKI, T. Über den lichtfaktor in den planzen-gasell-schaften und seine bedeutung fur die stoffproduktio. Japan Journal Botanic, v. 14, p.22-52, 1953.

MONTEITH, J.L. Climate and efficiency of crop production in Britain. Philosophical Transactions of the Royal Society of London, v.281, p.277-294, 1977.

MUNIIZ-MIRET, N; VAMOS, R.; HIRAOKA, M. et al. The economic value of managing the açai palm (Euterpe oleracea Mart) in the floodplains of the Amazon estuary, Pará, Brasil. Forest Ecology and Manegement, v.87, n.1/3, p.163-173, 1996.

NAIR, P.K.R. Agroforestry systems in the tropics. London: Kluwer, 1989. 664 p.

NODARI, O. R.; REIS, M. S.; FANTINI, A. C. et al. Crescimento de mudas de palmiteiro (Euterpe edulis Mart.) em diferentes condições de sombreamento e densidade. Revista árvore, v.23, n.3, p.285-292, 1999.

NOGUEIRA, N. J. Palmito: produção, pré-processamento e transformação agroindustrial. São Paulo: FEALQ, 1980. 109p. (FEALQ. Série Extensão Agroindustrial, 6) 
NOGUeIRA, O. L.; CAlZAVARA, B. B. G.; MÜlleR, C. H. et al. Manejo de açaizeiros (Euterpe oleraceae Mart) em latossolo amarelo na Amazônia. Revista Brasileira de Fruticultura. v.20, n. 1, p.53-59. 1998.

NOGUEIRA, O. L.; CARVALHO, C. J. R.; MÜLLER, C. H. et al. A cultura do açaí. Brasília: EMBRAPA-SPI, 1995. 50p. (Coleção plantar, 26).

ONG, C.K.; HUXLEY, P. Tree-crop interactions: a physiological approach. Wallingford: CAB \& ICRAF, 1996. 386p.

ONG, C. K.; CORLETT, J. E.; MARShALL, F. M. et al. R. Principles of resource capture and utilization of light and water. In: ONG, C. K.; HUXLEY, P. (Ed.) Treecrop interactions: a physiological approach. Wallingford: CAB \& ICRAF, 1996. cap.4, p.73-158.

PAULILO, M. T. S. Ecofisiologia de plântulas e plantas jovens de Euterpe edulis Mart. (Arecacea): comportamento em relação a variação de radiação solar. Sellowia, n.4952, p. 93-105, 2000.

PEDROSA MACEDO, J. H. O palmito no reflorestamento. Revista Floresta, v.4, n.2, p.57-59, 1973.

PELACANI, C. R.; OLIVEIRA, L. E. M.; SOARES, A. M. et al. Relações hídricas de algumas espécies florestais em substrato inundado. Revista Árvore, v.19, n.4, p.548$558,1995$.

PINHEIRO, G. S.; MARIANO, G.; CRESTANA, C. S. M. Estudo do desenvolvimento inicial do palmiteiro Euterpe edulis Mart., sob diversas condições de sombreamento, em plantio de Pinus kesiya Roule ex Gordon. São Paulo: Instituto Florestal, 1988. p. 171-180. (Boletim Técnico IF, 42).

POLLAK, H.; MATTOS, M.; UHL, C. O perfil da extração do palmito no estuário Amazônico. Belém: IMAZOM - Instituto do homem e meio ambiente da Amazônia, 1996. 32p.

REIS, M. S.; NODARI, R.O; GUERRA, M. P. et al. Desenvolvimento do palmiteiro: caracterização até os dezoito meses de idade sob diferentes níveis de sombreamento. In: ENCONTRO NACIONAL DE PESQUISADORES SOBRE PALMITO, Curitiba, 1987. Anais. Curitiba: EMBRAPA-CNPF, 1987. p.141-148. 
RICHARDS, P.; WILLIAMSON, G. B. Treefalls and patterns of understory species in a wet lowland tropical forest. Ecology,v.56, n. 5, p.1226-1229, 1975.

ROBAKOWSKI, P.; MONTPIED, P; DREYER, E. Plasticity of morphological traits in response to different levels of irradiance in seedling of silver fir (Albies alba Mill). Tree Structure and Function, v. 17, n.5, p. 431-441,2003

ROSA, L. dos S.; CRUZ, H. da S.; TOURINHO, M. M. et al. Caracterização dos quintais agroflorestais localizados nas várzeas do estuário Amazônico. In: CONGRESSO BRASILEIRO DE SISTEMAS AGROFLORESTAIS, 2, Belém, 1998. Anais. Belém: Embrapa-CPATU, 1998. p.161-166.

SÁ, T. D. A. Aspectos climáticos associados a sistemas agroflorestais: implicações no planejamento e manejo em regiões tropicais. In: CONGRESSO BRASILEIRO SOBRE SISTEMAS AGROFLORESTAIS, Porto Velho, 1994. Anais. Porto Velho: EMBRAPA, 1994. p.391-429.

SALISBURY, F. B.; ROSS, C. W. Plant physiology. 4.ed. Wadsworth, Belmont, CA. Wadsworth Publishing Company, 1992. 686p.

SAMPAIO, L. S. Respostas de plantas jovens de açaí à adubação fosfatada e à inundação em solos de várzea. Lavras, 1998. 150 p. Dissertação (Mestrado) Universidade Federal de Lavras.

SENTELHAS, P.C. Estimativa diária da evapotranspiração de referência com dados da estação metereológica convencional e automática. Piracicaba, 1998. 97p. Tese (Doutorado) Escola Superior de Agricultura "Luiz de Queiroz", Universidade de São Paulo.

SINCLAIR, R. T.; MUCHOW, R. C. Radiation use efficiency. Advances in Agronomy, v. 65, p. 215-261, 1999.

SINCLAIR, R. T.; SHIRAIWA, T.; HAMMER, G. L. Variation in crop radiation-use efficiency with increased diffuse radiation. Crop Science, v. 32, n.5, p. 1281-1284, 1992.

STEVEN, D.; WINDSER, D. M., PUTZ, F. E.; LEON, B. Vegetative and reproductive phenologies of a palm assemblage in Panama. Biotropica. v.19, n.4, p.342-356, 1987. 
STIRLING, C. M.; WILLIAMS, J. H.; BLACK, C. R. et al. The effect of timing of shade on development, dry matter production and light-use efficiency in groundnut (Arachisn hypogaea L.) under field condition. Australian Journal Agricultural Research, v.41, n.4, p.633-644,1990.

SVENNING, J. C. Recruitment of tall arborescent palms in the Yasuni National Park, Amazonian Ecuador: Are large treefall gaps important? Journal of Tropical Ecology, v.15, n.3, p.355-366, 1999.

SVENNING, J. C. Growth strategies of clonal palms (Arecaceae) in a neotropical rain forest, Yasuni, Ecuador. Australian Journal Botany, v.48, n.2, p.167-178, 2000a.

SVENNING, J. C. Small canopy gaps influence plant distributions in the rain forest understory. Biotropica, v.32, n.2, p.252-261, 2000b.

SVENNING, J. C. On the role of microenvironmental heterogeneity in the ecology and diversification of neotropical rain-forest palms (Arecaceae). The Botanical review, v.67, n.1, p. 1-53, 2001.

TOMLINSON, P. B. The structural biology of palms. New York :Clarendon Press, Oxford; Oxford University Press, 1990. 476p.

VANDERMEER, J. H.; STOUT, J.; MILLER, G. Growth rates of Welfia georgii, Socratea durissima, and Iriartea gigantea under various conditions in a natural rainforest in Costa Rica. Principes, v.18, p.148-154, 1974

WALTERS, M. B.; REICH, P.B. Low light carbon balance and shade tolerance in the seedlings of woody plants: do winter deciduous and broad leaved evergreen species differ? New Physiologist, v.143, n. p. 143-154, 1999.

WILLEY, R. W.; REDDY, M. S. A field technic for separating above-and bellow interactions in intercropping and experiment with pearl millet groundnut. Experimental Agriculture., v.17, n.3, p.257-264, 1981.

WOODWARD, F. I. From ecosystems to genes: The importance of shade tolerance. Trends of Ecology Evolution, v. 5, n.4. p. 111-115, 1990.

YAMAZOE, G.S; MOURA NETO, B. V.; DIAS, A C. Comportamento de Euterpe edulis Mart. plantado sob diferentes intensidades luminosas. Boletim Técnico do Instituto Florestal de São Paulo, v.40a, p. 133-141, 1986. 
YOUNG, A. Agroforestry for soil conservation. 2. ed. Wallingford: CAB-ICRAF, 1997. 320p. 